\title{
Outsourcing Supply Contracts, Human Capital and Firm Capital Structure
}

\author{
S. Katie Moon Gordon Phillips*
}

January 1, 2014

\begin{abstract}
We examine the impact of outsourcing supply contracts on firm risk and firm capital structure. We find that firm outsourcing is associated with less risky firm cash flows. Despite these less risky cash flows, our results show that outsourcing firms use less financial leverage - in particular during the recent financial crisis. We show that the effect of outsourcing on financial leverage is more negative when firms operate in high value-added, high $R \& D$ industries. Examining firm financing decisions, we document that outsourcing firms are more likely to issue equity and private securities. Our results are consistent with outsourcing firms using less leverage to decrease the expected costs of financial distress on the firm's implicit and explicit contracting parties, thus increasing the incentives of employees and suppliers to invest in firm specific assets.
\end{abstract}

* Securities and Exchange Commission, and University of Southern California and NBER, respectively. Moon can be reached at MoonS@sec.gov, and Phillips can be reached at gordon.phillips@marshall.usc.edu. We thank Ashwini Agrawal, Tony Cookson, David Matsa, Alexandra Phillips, Michael Roberts, Giorgo Sertsios and seminar participants at George Washington University, Humboldt University, Tsinghua University, University of Colorado, University of Oregon, UBC Summer Finance conference and USC for helpful comments. All errors are the authors alone. "The Securities and Exchange Commission, as a matter of policy, disclaims responsibility for any private publication or statement by any of its employees. The view expressed herein are those of the authors and do not necessarily reflect the views of the Commission or of the author's colleagues on the staff of the commission." Copyright (c)2013 by Katie Moon and Gordon Phillips. All rights reserved. 


\section{Introduction}

Outsourcing and purchasing from supplier firms has been growing extensively in the 21st century, yet we know little about how outsourcing contracting decisions affect a firm's real and financial decisions. Evidence from the electronics, pharmaceuticals and automotive industries shows that the use of contract manufacturing has been growing significantly. In particular, the electronics industry outsourced $\$ 75$ billion to contract manufacturers in 2000 , representing $10 \%$ of total production (Plambeck and Taylor (2005)). In addition, firms have been signing extensive outsourcing contracts with outside firms to run their communication and informational technology operations.

We examine the effect of outsourcing on firm risk and capital structuring using a unique database of purchase (supply) contracts data that we collect from firm 10-Ks. In a complete contracting world, using outsourcing or purchase obligation contracts would not affect firm capital structure. However, with incomplete contracts between the firm and its real side claimants, outsourcing may affect financial structure through its effect on the firm's suppliers and employees. The effect on suppliers and employees can arise due to potential costs that financial distress could impose on them and, in particular, on relationship-specific assets.

We collect firm outsourcing data using web crawling and text parsing of firm 10-Ks following the SEC's rule that requires firms to report significant outside purchase contracts to investors in their financial statements. Our focus is on both domestic and international supply contracts as our data shows 45.4 percent of outsourcing purchase contracts are from the U.S. and Canada, with 21.1 percent of suppliers from Asia and the Pacific, and the remaining from Europe and other regions 1

On the real side, we find that firms that use outside supply contracts have less risky cash flows. Despite these less risky cash flows, our results show that outsourcing firms have less financial leverage. Given that less risky cash flows should be associated with higher leverage under the traditional tradeoff theory of capital structure, we investigate what characteristics of these firms drive this result. Outsourcing firms that have more external supply contracts have higher value added per worker and use less debt, especially when they operate in high $R \& D$, high value-added industries. We recognize that outsourcing is an endogenous decision and thus we instrument for the outsourcing decision using the geographic location of the firm; specifically how close it is to major ports, airports or border

\footnotetext{
${ }^{1}$ See Nunn and Trefler (2012), and Antras (forthcoming) for recent contributions to the international trade literature based on incomplete contracting and the property-rights theory of firm boundaries. Spencer (2005) and Helpman (2006) provide surveys of the earlier outsourcing and international trade literature. Also, see Handfield (1994), Levy (1995), Monczka and Trent (2003) for management literature on international outsourcing.
} 
crossings, and the transportation costs of the inputs of the products that the firm's industry produces.

Our results are consistent with outsourcing firms using less leverage to decrease the expected costs of financial distress on implicit and explicit contracting parties and to increase the incentives of contracting parties to invest in relationship-specific assets. Lower leverage decreases the chances of financial distress and bankruptcy and helps maintain the value of implicit and explicit contracts. Thus, conceptually we show that the effects of incomplete contracting go beyond ownership as in Grossman and Hart (1986), extending to how firms with outside supply contracts finance their operations.

Specifically, we consider several possible channels for how outsourcing decisions may affect a firm's capital structure and financing decisions. The first way outsourcing may interact with financial structure is through long-term contracts with suppliers. Grossman and Hart (1986) model how the decision to be vertically integrated versus maintain separate ownership can affect the incentives to invest ex ante in relationship-specific investments. They model how control rights should reside in parties for which ex ante investments are more critical. If both parties investments are important to the final outcome, the firms will be less likely to vertically integrate. In our context, firms in which relationshipspecific investments are important will be less likely to be vertically integrated and more likely to use outside supply contracts.

Firms thus use long-term contracts with suppliers to ensure supply, and suppliers use long-term contracts to guarantee a market for the specified production and to maintain ex ante incentives to invest in the business relationship, as in Grossman and Hart (1986). However, these outside supply contracts can be directly affected by financial leverage. Given that contracts in bankruptcy can be broken, the expected duration of the contract and the business relationship will be shorter when firms have a higher probability of bankruptcy. If contracting parties are investing in relationship-specific assets or resources, they may be worried about the counter-party firm's financial stability, especially when there is a possibility of bankruptcy or financial distress resulting in a failure to fulfill the implicit or explicit contractual terms.

One possibility is that suppliers will internalize this possibility and require compensating contractual differentials when dealing with a highly leveraged firm. Alternatively, following the ideas of Williamson (1979), firms may attempt to minimize contracting costs and maximize the incentives to invest in the relationship through the use of lower leverage. Thus, conditional on longer term contracts being desirable for the firm, the firm may use less debt ex ante to decrease the probability of bankruptcy and financial distress in order to obtain more favorable contractual terms.

The second way outsourcing may affect financial structure is through its effect on a firm's human 
capital and type of employees. The idea is similar to the previous effect on suppliers in that the firm faces a limited commitment problem and is not able to contractually insure its employees through complete contracts in the event of bankruptcy or financial distress. If outsourcing firms employ more high value-added employees who should optimally invest in firm-specific human capital, the firms will choose a financial structure that increases these incentives. As Jaggia and Thakor (1994) model, higher financial leverage can decrease employees' incentives to invest more in firm-specific assets as the bankruptcy can cause the value of their firm-specific assets to decrease. Thus the firm will optimally take on a lower amount of debt to counteract the effect of potential bankruptcy on an employee's incentive to invest in relationship specific capital.

The reasoning is that an increase in the probability of bankruptcy that lessens the likelihood that long-term wage commitments will be honored ex post imposes a greater cost on firms and employees when the firm has greater investment specificity. Such a firm, therefore, is predicted to optimally take on a lower amount of debt. Berk, Stanton, and Zechner (2010) analyze the human cost of bankruptcy more generally. Their model shows that even without firm-specific human capital, more human capital intensive firms will have less financial leverage as the optimal contract involves firms providing a more stable fixed compensation contract when employees are risk averse with respect to their human capital. This idea has other empirical support. Bankruptcy and financial distress have been recently shown to affect a firm's ability to hire high quality employees as the number and quality of job applicants decrease with an increase in financial distress, as Brown and Matsa (2013) recently show. Lastly, firms may also use less leverage to help insure workers as in Agrawal and Matsa (forthcoming 2013).

After examining the amount of financial leverage firms use, we examine firms' financing decisions more closely. We examine whether outsourcing affects the source of debt and equity that firms use. The idea we investigate is whether firms that use long-term agreements with suppliers and employees have a more flexible financial structure. Given that private debt with fewer creditors is more flexible and easier to renegotiate than public debt, as Bolton and Scharfstein (1996) model, firms that use debt and wish to have more flexibility in their capital structure are predicted to use more private debt. We find support for this prediction.

Our results show that there is a real effect of outsourcing through firm contracts and firm employees and that this real side effect also manifests itself in firm financing decisions. First, on the real side, we show that there is a reduction in firm cash flow volatility and this reduction was particularly evident during the recent financial crisis. During the recent financial crisis, outsourcing firms were able to better match costs with sales fluctuations. Firms that use long-term purchase contracts incur fewer fixed costs thus reducing their operating leverage. Second, on the financial side, we show that despite 
the reduction in cash flow volatility, outsourcing firms use less financial leverage. This reduction in leverage is especially found in outsourcing firms in high $R \& D$, high value-added industries. Third, we find that when outsourcing firms issue securities, they are more likely to issue private securities. When issuing debt, they are more likely to choose private debt over public debt. Thus, outsourcing firms are more likely to use less debt and change the composition of their debt to include more private debt, as they have proportionally more high value added employees and contracts with external suppliers.

Our results are robust to taking into account that long-term contractual outsourcing decision is itself an endogenous decision. We use the geographic location of the firm; specifically how close it is to major ports, airports or border crossings to instrument for the outsourcing decision. We also use the transportation costs of the inputs of the products that the firm's industry produces. The idea is that geographic location can make it easier for some firms to outsource production but should have limited or no impact on financing decisions of firms other than through the outsourcing decision after controlling for industry: $2^{2}$

Our results are consistent with contracting affecting not only who should own the asset but also the amount and composition of external financing. In our context of separate ownership with long-term contracts, our results are consistent with firms choosing more flexible capital structures through the use of equity and private debt in order to reduce the costs of financial distress on employees and suppliers. The implication of our results is that contracting counter-parties of a firm will be more willing to invest in specialized assets and maintain these assets when the firm uses less debt and less publicly traded debt to finance its operations since then the firm has a greater chance of long-term survival.

Our paper adds to several literatures. We add to the outsourcing literature (see Antras (forthcoming) for recent contributions and Spencer (2005) and Helpman (2006) for more extensive surveys) and show that there is a financial dimension to outsourcing that has not been studied before. Conceptually, we add to the incomplete contracting literature showing that incomplete contracting and relationship-specific assets affect firm financing decisions. Previous literature, including both the theoretical literature beginning with Grossman and Hart (1986) and the empirical literature such as Baker and Hubbard (2004) that is based on these ideas, shows that residual rights of control affect firm ex ante incentives to invest in relationship-specific assets and thus who should own the assets. However,

\footnotetext{
${ }^{2}$ Geographic proximity has also been used to study investment in local plants by Giroud (2012). In our case, geographic location directly impacts investment but should not affect financing decisions except through the effect of location on the type of investment.
} 
this literature does not deal with how the assets should be financed and whether capital structure is influenced when firms choose not to integrate. Our paper shows that outsourcing supply contracts impact the capital structure of the firm and the source of its debt and equity financing.

We also add to the literature that studies labor-finance interactions on how the composition of a firm's labor force and its assets interact with its financial leverage and financing decisions (Jaggia and Thakor (1994), Berk, Stanton, and Zechner (2010) and Brown and Matsa (2013)). Lastly, we add to the literature on customer and supplier relations. Allen and Phillips (2000) show that firms with product market relationships where one party owns equity in another experience better operating performance and more investment. Fee, Hadlock, and Thomas (2006) show that firms are more likely to invest in ownership positions in firms in which they have business relations. Kale and Shahrur (2007) show that competition and the characteristics of customers and suppliers affect firm financial structure.

The remainder of this paper proceeds as follows. Section 2 describes data we use, and in particular, the long-term outsourcing contracts. Section 3 discusses our identification strategy and empirical methodology. Section 4 presents our results on the effect of outsourcing, employees and suppliers on financial structure and examines the public versus private financing choices of outsourcing firms. Section 5 concludes.

\section{Data and Summary Statistics}

\subsection{Purchase Contracts Data}

We examine purchase obligations data from public firms that we download and process electronically from the SEC's Edgar 10-K filings website. Our data begins in 2004, since in January 2003 the SEC issued a final rule on Disclosure about off-balance sheet arrangements and aggregate contractual obligations ${ }^{3}$ This rule requires all public companies other than small business issuers to provide an explanation of their contractual obligations in a separately captioned subsection of the Management's Discussion and Analysis (MD\&A) section. U.S. GAAP already requires firms to aggregate and assess all of the specified categories of contractual obligations: long-term debt obligations, capital lease obli-

\footnotetext{
${ }^{3}$ This rule is to implement Section 401(a) of the Sarbanes-Oxley Act of 2002. See Final Rule: Disclosure in Management's Discussion and Analysis about Off-Balance Sheet Arrangements and Aggregate Contractual Obligations, Securities Act Rel. No. 33-8182, Exchange Act Rel. 34-47264, Financial Reporting Rel. No. FR-67, International Series Rel. No. 1266, http://www.sec.gov/rules/final/33-8182.htm (Jan. 27, 2003).
} 
gations, and operating lease obligations. However, the SEC's final rule on disclosure about contractual obligations in January 2003 particularly includes the "purchase obligations" category.

The SEC defines a purchase obligation as an agreement to purchase goods or services that is enforceable and legally binding on the registrant in the future. Therefore, a firm's purchase obligations represent the amount of inputs in production that will be purchased in the future (Lee (2010)). Purchase obligations are different than open-market orders in that a company legally signs purchase contracts with third parties. Thus, purchase obligations capture a firm's contractual outsourcing activity.

For the fiscal years ending on or after December 15, 2003, all public firms (other than small business issuers) started disclosing purchase obligations in their financial statements. Therefore, our primary sample includes all 10-K filers in the manufacturing sector associated with fiscal years ending in 2004 and up to 2010. We also gather information on the suppliers and their country using suppliers disclosed and identified by Capital IQ.

Firms generally do not sub-categorize purchase obligations in their tabular disclosures. They sometimes provide limited information on the types of purchase obligations in their following footnotes. For manufacturing firms, the most common type of purchase obligation is an inventory purchase commitment. A service agreement, including advertising, marketing and IT, is another common type of purchase obligation 4 The payment due is classified by specified periods in the tabular disclosure format. Firms commonly disclose total amounts of purchase obligations and then break those amounts into the specified periods (e.g. within one year, between one and three years, between three and five years, and beyond five years). Purchase obligations due within the one year category must exist in the disclosure, while firms can arbitrarily choose to report other future periods. In general, the purchase obligations due beyond one year are frequently minimum amounts specified in the contracts that the firm must purchase from the counter parties. Therefore, the purchase obligations beyond one year sharply fall over time, and do not capture the correct amounts of purchase contracts for the specified longer period. Hence, we use the amount of purchase obligations within the closest fiscal year, normalized by cost of goods sold for our measure of outsourcing intensity.

Figure 1 shows an example of Apple Inc.'s purchase obligations disclosure in its 10-Ks. We present purchase obligations data for Apple Inc. for 2005 and 2008. From the data presented, we can see that purchase obligations have increased almost three-fold for Apple Inc.

\footnotetext{
${ }^{4}$ See Lee (2010) for discussion about the across-industry variation in the type of purchase obligations.
} 


\section{[INSERT FIGURE 1] HERE]}

Appendix A gives three further detailed firm examples in the semiconductor industry to illustrate the relation between outsourcing and leverage that we explore both cross-sectionally and in time series. The examples show that companies within the same industry have different outsourcing strategies. Marvell Technology Group is a leading fabless semiconductor company while Fairchild Semiconductor owns continuously operating semiconductor manufacturing facilities. Xilinx has changed its outside purchase obligations over time and provides more variation in its outsourcing intensity. All three companies operate in the same geographic region.

The appendix shows large cross-sectional differences between Marvel Technology and Fairchild. Fairchild owns and operates semiconductor facilities and has significantly higher leverage than Marvel Technology which does not own its own semiconductor facilities. Marvel Technology has almost no financial leverage. The last firm in Appendix A, Xilinx, has experienced variation in outsourcing over time. It thus illustrates the within firm time-series relation between outsourcing and leverage. What is also interesting to point out is that there is a sharp decrease in outsourcing that occurs for all three firms during 2008, the year after the financial crisis began. Firms are thus able to change the amount of outsourcing in subsequent years as demand conditions fluctuate.

\subsection{Sample}

We gather purchase obligation data using "web crawling" of the SEC Edgar website and downloading firm 10-Ks using PERL scripts. We provide the detailed collection procedure in Appendix B. After downloading the firm $10-\mathrm{Ks}$, we parse the documents to extract the actual purchase contracts data 5 We extract this data from either tables or text where search keywords indicate the presence of purchase obligations data. The search keywords we use are the combinations of "purchase" and one of the following terms: "obligation", "commitment", "agreement", "order" or "contract". From the tables or text including the search terms, we extract the rows that contain the amount of purchase obligations. We link this data to the Compustat database and to the security issuance decisions that we describe later in this section.

We study public manufacturing firms, given that production outsourcing prevails in the manufac-

\footnotetext{
${ }^{5}$ Lee (2010) first collects and studies purchase obligations data. The description of his data can be found at http://faculty.haas.berkeley.edu/klee/Kwang Lee Purchase Obligations Data.htm. Also, a contemporaneous paper by Williams (2012) uses similar data to explore supplier-customer contracts.
} 
turing sector, while purchase contracts in the service sector may exist just to supply finished goods that are then resold. We create the primary sample by merging all of the public manufacturing firms in the 10-K filings database to the CRSP/Compustat database by the central index keys (CIK). We exclude firms whose sales revenue is less than $\$ 50$ million because they are regarded as small business issuers which are not required to disclose contractual obligations ${ }^{6}$

This sample construction procedure leaves us with 1,806 firms operating in 20 different 2-digit SIC code industries and about 9,000 firm-years during the sample period from 2004 to 2010. We supplement this database with a new security issues database and a supplier database that we create by obtaining financial security issues and supplier information from the Securities Data Corporation (SDC), DealScan, and Capital IQ databases. In the rest of this section, we describe the purchase contracts data and the other data we analyze in detail.

Table I presents industry descriptive statistics for purchase obligations by 2-digit SIC code industry in the manufacturing sector. We assume that if the firm does not disclose an amount of purchase obligations in its $10-\mathrm{K}$, it has no contractual purchase obligations $\mathrm{7}^{7}$

\section{[INSERT TABLE I HERE]}

Table 1 shows that across all industries more than $65 \%$ of manufacturing firms use outside purchase contracts, and the mean value of purchase obligations reaches about $10 \%$ of the total cost of goods sold. The last two columns show that outside purchase contracts comprise almost $15 \%$ of the total cost of goods sold within firms with non-zero purchase obligations. Inspection of the table also shows that outsourcing is not just in high-technology industries; outsourcing intensity is also high in food and kindred products, paper products, petroleum and coal products, and leather products.

\footnotetext{
${ }^{6}$ The SEC defined a small business issuer as a company that had less than $\$ 25$ million in revenues in its previous fiscal year, and whose outstanding publicly-held stock is worth no more than $\$ 25$ million. In 2008 , the SEC adopted a new terminology of 'smaller reporting companies' and amendments to its disclosure and reporting requirements to expand the number of companies that qualify for smaller reporting companies. In the new amendments, smaller reporting companies are defined as companies that have less than $\$ 75$ million in public equity float, or less than $\$ 50$ million in revenues in the previous fiscal year if public equity float is not calculable.

${ }^{7}$ The SEC's final rule adopted the "reasonably likely" disclosure threshold that currently applies to other portions of MD\&A disclosure. As stated in the SEC's 1989 MD\&A Release, a company has an obligation to disclose prospective information in its MD\&A "where a trend, demand, commitment, event or uncertainty is both presently known to management and reasonably likely to have material effects on the company's financial condition or results of operations".
} 


\subsection{Customer and Supplier Relationship Data}

We examine the potential reasons for the impact of outsourcing on firm financial structure in depth by exploring customer and supplier relationships identified in the Capital IQ business relationship database. Previous studies use either the input-output benchmark table from the Bureau of Economic Analysis or the customer data from the Compustat segment file to identify customer and supplier relationships. However, the input-output benchmark table represents interdependencies between industries, not between firms. Also, the Compustat customer data do not include business relationships with foreign or private supplier firms, as the database only compiles information on major customers of U.S. public firms. On the other hand, the Capital IQ database collects data on foreign or private suppliers and provides information on their revenue, assets, total number of employees, SIC code, and main business location, by compiling more than 20,000 news sources. Note that we cannot identify the extent each supplier supplies the firm as these suppliers are just listed by name and not by the amount of goods that they supply.

We identify approximately 7,000 suppliers (3,726 unique suppliers as some suppliers supply more than one firm) for 882 customer firms by merging our sample and Capital IQ database with the customer firm's CIK, ticker, or name. On average, customer firms in our sample have 7.75 suppliers. Our focus is on both domestic and international supply contracts as we find that 46.2 percent of outsourcing purchase contracts are from the U.S. and Canada, with 20.9 percent of suppliers from Asia and the Pacific, 15.5\% from Europe, 1.8\% from Africa/Middle East, 1.1\% from Latin America/Caribbean, and $14.5 \%$ from countries we are not able to identify. Most of the suppliers are in the manufacturing sector $(47.4 \%)$. Other than manufacturing, the suppliers are in the following industry sectors: services $(17.2 \%)$, retail and wholesale trade $(2.5 \%)$, transportation and utilities $(3.2 \%)$, mining $(2.0 \%)$, others $(2.5 \%)$ and unknown $(25.2 \%)$.

\subsection{Security Issuance Data}

We study the impact of outsourcing activity on financing decisions by U.S. public manufacturing firms from 2005 to 2011. We classify corporate financing in 6 different types by issuing markets and securities; first by public versus private market and second by debt, convertible versus equity. We include both convertible preferred stock and convertible debt in the convertible security category.

The security issuance data come from the three different databases. We obtain public securities issuance data from the SDC new issues database. The SDC new issues database also provides private 
securities data, but its coverage of private placement is minimal and incomplete 8

Our private debt placement data come from the DealScan database of the Loan Pricing Corporation. A private placement is an unregistered offering of securities by a public firm to a selected group of investors.9 The DealScan database contains private placement information including term loans and revolving credit lines made to U.S. firms by banks and syndicates of lenders (Gomes and Phillips (2012)). Following Gomes and Phillips (2012), we exclude 364-day facilities and any other loan with less than one year of maturity from our sample.

Our private equity and convertible securities consist of private equity investments in public companies data (frequently called PIPEs for private investment in public equity) and comes from the Capital IQ database. The Capital IQ database provides comprehensive and detailed information on transaction features and market participants in the private transactions, especially after 1999 10

Table II gives the summary statistics of the issuance decisions. We can see that the private markets are significant for public firms. Approximately 60 percent of security issuances are private debt.

\section{[INSERT TABLE[I] HERE]}

In addition to the public and private securities, we also include Rule 144A issues in our sample, but we aggregate them with other security types as Rule 144A securities are not a large part of the issuance activity. Rule 144A issues have three security types; Rule 144A debt, convertibles, and equity. Most of the Rule 144A issues by public firms are in the debt form, either debt or convertible debts. Rule 144A debt securities are similar to medium-term notes, but they are unregistered and also offered to only Qualified Institutional Buyers (QIBs). In general, QIBs are large domestic or foreign institutional investors that in aggregate own and invest at least $\$ 100$ million in securities ( $\$ 10$ million for a broker-dealer) 11 As in Gomes and Phillips (2012), the institutional details indicate that 144A

\footnotetext{
${ }^{8}$ The number of private debt issues in the SDC database is less than one-tenth of the number in the DealScan database. Our private equity and convertibles issue data come from the Capital IQ. The Capital IQ database has three times as many private convertibles securities data as the SDC database. The number of private equity issues (PIPEs) in the SDC database is comparable to that in the Capital IQ database.

${ }^{9}$ For example, according to the SEC's Rule 505 of Regulation D, a company can offer Regulation D (Reg D) securities to an unlimited number of "accredited investors" and up to 35 other persons who do not need to satisfy the sophistication or wealth standards associated with other exemptions. The Reg D securities are "restricted" securities, meaning that the securities cannot be re-sold for six months or longer without potentially needing to register the re-sales. The issuers cannot use general solicitation or advertising to sell the securities.

${ }^{10}$ See Stromberg (2008), Lerner, Sorensen, and Stromberg (2011), and Hsu, Reed, and Rocholl (2012) for further discussions on the Capital IQ database.

${ }^{11}$ In addition to the qualification above, banks and savings and loan associations that have a net worth of at least $\$ 25$ million are regarded as QIBs.
} 
issues and public issues are similar. Thus, in Table III and throughout the rest of our analysis, we combine Rule 144A securities with other public securities - either debt, equity, or convertibles.

We merge all the above security databases with the purchase obligation database in the previous section and the CRSP/Compustat database 12 Following Huang and Ritter (2009), firm years in which multiple types of securities are issued are excluded from the sample, but results are robust when we include these issuance observations.

Table III shows summary statistics for issuance decisions and the issuing firms' outsourcing intensity captured by their purchase obligations scaled by cost of goods sold. Table III shows that both security issuance decisions and outsourcing decisions vary strongly with firm size. Firms that issue public debt are larger with most of the firms in the upper four deciles of the market value of assets. Private debt and equity issuers exist at all deciles of firm size. Equity issuers in particular are skewed to smaller firms, especially so for private equity issuers. With respect to outsourcing intensity, we can see that outsourcing firms tend to be larger firms, especially firms that issue convertibles and private debt securities. By comparing private versus public issues for each security, we also find that firms that use the private market to issue any type of security tend to have greater outsourcing intensity in each firm size category.

[INSERT TABLE III HERE]

\section{Empirical Strategy and Variables of Interest}

We analyze the effect of outsourcing decisions on financial leverage and security issuance decisions. However, outsourcing firms are not randomly selected, so we face the identification problem that both outsourcing and financing decisions may result from common factors, such as demand conditions or cost shocks. Empirical evidence from the data suggests that outsourcing propensity (whether to outsource or not) is relatively more invariant than other corporate decisions. However, outsourcing intensity (how much to outsource) is associated (as we show later) with the firm's growth and cash flow stability, which, in turn, are highly likely to be related to financing decisions. Therefore, we address this endogeneity problem using instrumental variables. We begin by discussing our instrumental variable regression approach and the instruments we use. Also, in this section we discuss the control variables

\footnotetext{
${ }^{12}$ To match the private debt placement data from the DealScan database to other databases, we use the DealscanCompustat link file provided by Chava and Roberts (2008) through the WRDS website. To merge private equity and convertible placement data from the Capital IQ, we use the CIKs along with the exchange-ticker information.
} 
we use in our analysis.

\subsection{Proximity to Sourcing Locations and Input Transportation Costs}

A valid instrument for our analysis is a variable that affects the amount of outside purchase contracts, but whose effect on the firm's financing decisions comes through the outsourcing channel. It has to thus be relevant and also satisfy the exclusion restriction. The instruments we use are 1.) the distance to the closest port of entry including seaports, hub airports, and border crossings and 2.) the transportation cost of inputs used in the industry. Given that a firm's location is relatively permanent and the industry transportation costs of inputs used are at the industry-level, it is likely that both instruments do not affect a firm's capital structure choices over time except through the outsourcing channel.

In particular, the distance to the closest seaport (for water transportation) has been used as an exogenous instrument in Fort (2011) and Moon (2012). Fort (2011) shows that plants over 200 miles away from a deep water port are 2.4 percentage points less likely to fragment (outsource) relative to plants within 50 miles of the closest port. Moon (2012) also shows that whether the firm is close to the seaport is associated with a 1.2 percentage point increase in a firm's outsourcing intensity.

We construct our measure of a firm's proximity to potential sourcing locations by calculating the distance between the firm's main business location and its closest port of entry among seaports, airports, and border crossings. The information of the U.S. seaports are provided by the Port Import Export Reporting Service from the Maritime Administration's website. We identify 48 seaports within the U.S. 50 states that carry imports with a value of 500 TEUs or greater ${ }^{13}$ The information of the U.S. airports are available on the Passenger Boarding and All-Cargo Data for U.S. Airports from the Federal Aviation Administration website. We identify 105 hub airports with cargo services using the information. In addition, we identify 21 Mexican border crossings and 79 Canadian border crossings with truck traffics.

We obtain latitude and longitude for these ports of entry and firms' main business locations, then calculate the great-circle distances between the firm's main business location and its closest port of entry. Figure 2 shows firm main business locations and also the locations of the ports, border crossings and hub airports. From these maps we can see that many firms are some distance from

\footnotetext{
${ }^{13} \mathrm{~A}$ TEU is a nominal unit of measure equivalent to a $20 \times 8 \times 8$ shipping container. The results remain similar, when we use 100,300 or 500 TEUs for the cutoff.
} 
external sourcing locations, especially in the, West Midwest and locations in the East region such as Connecticut.

\section{[INSERT FIGURE 2 HERE]}

The distance to the closest port of entry captures the firm's feasibility to purchase products or services from suppliers in other countries or other states far from a firm's location. It is likely to be an exogenous instrument that affects a firm's transportation costs from potential sourcing locations. The closest port of entry is likely to affect a large number of U.S. manufacturing firms that hire foreign suppliers, and thus is an important factor in the firm's decision to increase or decrease its level of outsourcing.

We use both cross-sectional between and time series regressions to predict outsourcing decisions. The economic interpretation is that the cost of external outsourcing is different between firms and is also changing over time thus allowing variation in the advantages of being closer to a sourcing location. In our regression analysis, we mainly use a discretized version of the distance to the closest port of entry. This variable, close to port of entry, equals 1 if the minimum distance to any entry ports is in the lowest tercile of the sample. This discretization allows for a likely nonlinear relation. For robustness, we have also used different cutoffs including below the median and similar results obtain.

We create the industry-level transportation costs of inputs used using the 2002 input-output use tables from the Bureau of Economic Analysis ${ }^{14}$ At the detailed IO-code level, the input-output use tables provide railroad, truck, water, air, pipeline and gas transportation costs, which indicate the costs to deliver inputs from other industries to the industry of interest. We aggregate the transportation costs across all transportation methods at each input industry level. Then, we capture each industry's average input transportation costs by calculating the purchase value-weighted average of the transportation costs across all input industries. A discretized version of this variable indicating high input transportation cost industries is used in our regression analysis. The variable, high transp cost, equals one when it is in the highest tercile of the sample.

We conduct a set of tests to verify that the geographic location and the transportation costs variables are valid instruments. All instrumental variable regressions pass the weak, under- and overidentification tests. In the leverage regressions discussed later for example, the F-test statistic of excluded instruments is 10.85 . The regressions are not under-identified with Kleibergen-Paap LM

\footnotetext{
${ }^{14}$ Input output benchmark tables are publicly available from the website of Bureau of Economic Analysis at http://www.bea.gov/industry/io_benchmark.htm.
} 
statistic of 17.21 and also not over-identified as the Hansen's J-statistic is 3.32.

\subsection{Industry and Firm-specific Variables}

In our analysis of firms' financial decisions, we include the firm-specific variables that have been shown to influence security issuance decisions by Gomes and Phillips (2012). These variables include downstream demand shocks, a firm's default probability, the proportion of tangible assets, cash flow volatility, stock return volatility, abnormal stock returns, the percentage foreign tax a firm pays out of total taxes and a firm's marginal tax rate from Graham (1996). We include the percent foreign tax to control for the fact that outsourcing firms may use less leverage as their foreign operations may be subject to less taxation, thus reducing the need for leverage as a tax shield. Details on the control variables other than the variables below that require more processing are available in Appendix C.

To examine how outsourcing firms respond to demand shocks, we create a measure of downstream demand changes and compare the factor loadings for this variable between outsourcing and nonoutsourcing firms. We capture each industry's demand condition using the chain-type quantity indexes for gross output by industry from the U.S. Department of Commerce's Bureau of Economic Analysis (BEA). The BEA provides publicly available series on gross output by industry at the detailed IO-code and NAICS level. For consumer and government demand, we use personal consumption indexes and government spending and investment indexes, which we also obtain from the Bureau of Economic Analysis ${ }^{15}$ We then link these data to each supplier industry by a downstream matrix using the input-output benchmark table from the Bureau of Economic Analysis. A downstream industry is defined as an industry that uses the industry's output in the input-output use table ${ }^{16}$

Following Maksimovic and Phillips (2001), demand shock is the detrended annual percentage change in the downstream industry demand. To detrend, we regress the raw downstream industry demand on industry and year fixed effects indicator variables and then take the residuals from the regression. To capture the response to industry downturns, we use a discretized version of this variable indicating negative demand shocks in our regression analysis. This variable, "negative demand shock", equals one when demand shock is negative and zero otherwise.

\footnotetext{
${ }^{15}$ These data are available at http://www.bea.gov/industry/gdpbyind_data.htm, for the period of 19982011. For the chain-type quantity indexes for gross output by industry, we specifically use the data at http://www.bea.gov/industry/xls/GDPbyInd_GO_NAICS_1998-2011.xls.

${ }^{16}$ Input output benchmark tables are publicly available from the website of Bureau of Economic Analysis at http://www.bea.gov/industry/io_benchmark.htm. We use the 2002 standard use tables at the detailed IO-code level, and match this data into NAICS codes by correspondence tables between IO and NAICS codes.
} 
We also include a measure of default probability as an indicator of financial distress. We construct a measure of the probability to default based on Bharath and Shumway (2008) default probability, which is also based on the Merton (1974). The main idea of the Merton's default probability is to compare a firm to a bond using the standard deviation of its equity and the value of its debt. It is theoretically derived and depends on the basic elements of a firm's risks.

We choose this measure over the other traditional distress measures such as Altman's Z score. Altman's Z score is constructed using Multi-Discriminant Analysis (MDA) technique, which is similar to econometric regressions that select the financial factors with the best ability to separate out distressed firms from non-distressed firms. However, the $\mathrm{Z}$ score is not robust to changes in industry financial structure including the increasing trend in operating leases ${ }^{17}$ In addition, Merton's naive default probability measure based on the approach in Bharath and Shumway (2008) predicts the bankruptcy episodes in the airline industry far better than Altman's Z score (Phillips and Sertsios (2012)).

We compute the Merton's default probability using daily stock price information from the CRSP database and debt value information from the Compustat database. The formula for a firm's probability to default is $\pi=\mathcal{N}\left(-\frac{\ln (V / D)+\left(\mu-0.5 \sigma_{V}^{2}\right) T}{\sigma_{V} \sqrt{T}}\right)$, where $\mu$ is the expected return on the firm's asset, $V=E+D$ is the market value of the firm, $E$ and $D$ are the market value of the firm's equity and debt respectively, and $\sigma_{V}=(E / V) \sigma_{E}+(D / V) \sigma_{D}$ is the standard deviation of $V$. Following Bharath and Shumway (2008), we proxy $D$ to the face value of the firm's debt and the standard deviation of the firm's debt with $\sigma_{D}=0.05+\sigma_{E}$. We assume the forecast horizon of 1 year $(T=1)$, and then approximate the expected return on the firm's asset as the firm's stock return over the previous year.

To control for industry- and year-specific factors, we include the 25-Fixed Industry Classifications (FIC) dummies made available by Hoberg and Phillips (2010a) and year dummies ${ }^{18}$ For robustness, we also include the economy-wide variables (Aaa bond yield and a credit spread between Baa and Aaa bond yield) instead of using year-fixed effect estimations, to capture aggregate market conditions. Also, we control for industry competition from Hoberg and Phillips (2010a)'s Text-based Network Industry Classifications (TNIC) industries and a high-tech industry indicator variable, to capture industry-wide effects.

\footnotetext{
${ }^{17}$ See Gavazza (2011).

${ }^{18}$ In unreported results, we use 3-digit SIC or 4-digit NAICS codes instead. Results are robust to these industry classifications.
} 


\subsection{Summary Statistics}

In this section we present summary statistics for our key variables (outsourcing intensity and leverage) along with other control variables we include in our regressions. These variables are firm size as captured by the market value of assets, firm market to book, profitability, sales growth, abnormal stock returns, cash flow and stock market volatility, competition from the Hoberg and Phillips (2010a) TNIC industries, and a high-tech industry indicator variable.

[INSERT TABLE IV]HERE]

Table IV presents summary statistics for outsourcing and non-outsourcing firms separately and test for significant differences across these groups of firms. The table shows that nearly all control variables are significantly different across outsourcing and non-outsourcing firms. Inspection of the table also reveals that operating margins and the return on assets are higher for outsourcing firms. Thus, the outsourcing firms are more profitable. Outsourcing firms are larger, older, with less debt and higher market to book than non-outsourcing firms.

The table also shows that outsourcing firms are less risky than non-outsourcing firms. The default probability and the standard deviation of the operating margin and return on assets are significantly lower for outsourcing firms than for non-outsourcing firms. Lastly, outsourcing firms are in more competitive, high-technology industries. The picture that emerges from these results is outsourcing firms are larger, less risky, more profitable firms that have significantly lower leverage than nonoutsourcing firms.

\section{Results}

The basic questions we address are the following: First, is outsourcing associated with a decline in firm risk? Second, what are the characteristics of firms that outsource? Third, do firms that sign outsourcing contracts use more or less leverage and are the outsourcing firms more or less likely to use private or public markets as their source of capital?

We first examine the cash flow risk of firms that outsource. We do so in order to better understand the effect of outsourcing on firm business risk and to aid in our analysis of which firms outsource. This analysis of which firms outsource is used in later regressions to explicitly control for the endogeneity of the outsourcing decisions in order to establish a channel from outsourcing to financial structure. 
We examine these questions with a combination of propensity score matching models and regressions that instrument for the outsourcing decision to take into account the endogeneity of the outsourcing decision. We are testing the theoretical proposition that firms and their employees and suppliers are investing in relationship specific assets when they do business with each other, since the firms cannot sign complete contracts to cover every contingency, especially in financial distress and bankruptcy. Thus, to increase the incentives to invest in these relationship specific assets, we would expect that firms for which relationship specific investments are more important will choose less risky financial contracts.

\subsection{Outsourcing and Firm Risk}

In this section, we examine the risk of outsourcing firms by examining cash flow volatility using propensity score based matching methods. We consider the standard deviation of operating income before depreciation from the 12 previous quarters scaled by sales, thus it does not include the effect of fewer fixed assets in outsourcing firms. To examine risk in a nonparametric way, we use a matching estimator and compare outsourcing firms to non-outsourcing firms. We match based on multiple variables which include size as captured by the market value of assets, market to book (M/B), market leverage, mean quarterly sales, competition from the Hoberg and Phillips TNIC industries, and a high-tech industry indicator variable. The outsourcing variable we consider in Table $\mathrm{V}$ is an indicator for whether a firm has purchase obligations ( $P O$ exists). It equals one if the firm has disclosed a non-zero amount of purchase obligations for the given fiscal year. The control observations are the 10 nearest neighbors across the matching variables with the same FIC-25 code from Hoberg and Phillips (2010a). In robustness tests, we also use as control observations firms from the same three-digit SIC or 4-digit NAICS codes.

\section{[INSERT TABLE V]HERE]}

Table $\mathrm{V}$ shows that cash flow volatility for outsourcing firms is lower in every quarter than that of non-outsourcing firms. In particular, cash flow volatility is significantly lower in 12 out of 16 quarters from 2007 to 2010. This indicates that the outsourcing firms were able to reduce their volatility when faced with the financial crisis.

In Table VI, we further investigate the source of this lower cash flow volatility by regressing firm cost of goods sold and SG\&A on an indicator variable that equals one when the firm experiences a negative demand shock. Our indication of a negative demand shock is when the downstream demand 
industry experiences a decline in sales. We scale cost of goods sold and SG\&A by the average sales of the firm to avoid an effect from changing sales over the period. The idea is to investigate whether outsourcing firms can scale their costs down when faced with a negative demand shock. We include firm fixed effects to focus on the firm-specific difference relative to their time series average in both their cost of goods sold and SG\&A.

\section{[INSERT TABLE VI HERE]}

The analysis presented in Table VI shows that the outsourcing firms' cost of goods sold combined with their SG\&A drops more than two times of the amount in non-outsourcing firms when there is a negative demand shock. These results show that outsourcing firms are able to significantly reduce their cost of goods sold and selling and general administration expenses and thus their cash flow volatility, when faced with negative demand shocks.

\subsection{The Outsourcing Propensity}

In this section, we report the results of our outsourcing propensity regressions. As discussed earlier, there is a potential endogeneity problem given that a firm's outsourcing activity and its financing decisions may respond to the same changes in common external factors. As the actual intensity of the firm's outsourcing activity is endogenous, we thus first instrument this variable with the geographic location and transportation costs variables for all firms in the manufacturing sector sample. We report these results in this section. Then, we use this predicted firm-year level outsourcing intensity measure to examine the impact on financing decisions.

We first estimate between regressions at the firm level, where each variable is collapsed into its time-series average. These specifications thus examine the cross-sectional heterogeneity in the outsourcing decisions. We report these results in columns one to two. We then estimate panel regressions at the firm-year level for outsourcing propensity. Standard errors are estimated that allow for heteroskedasticity and industry clustering for the firm-level regressions and industry-year clustering for the firm-year panel regressions. Depending on the column, we include industry and year fixed effects. We do not include firm fixed effects as the firms in our sample, over the time period we examine, do not change the geographic location of their main business locations.

We report several different specifications in Table VII. In the first two specifications - columns one and two of Table VII - we estimate a tobit model with a dependent variable that equals the amount of purchase obligations due within 1 year scaled by cost of goods sold. We use a between-regression model 
that regresses the firm time-series averages of outsourcing intensity $(P O / C O G S)$ on the time-series averages of the right hand side variables.

\section{[INSERT TABLE[VII HERE]}

Inspection of the results in Table VII reveal that, on average, being close to a port of entry results in a 1.4 percentage point increase in firm-level outsourcing intensity. Also, being in an industry with high input transportation costs results in a 2.3 percentage point decrease in firm outsourcing intensity.

The results also show that outsourcing intensity is significantly related to firm profitability and sales growth, as in Lee (2010) who documents that the growth in purchase obligations is associated with higher future sales and earnings. In addition, our results show that industry factors are important in explaining a firm's outsourcing intensity. A firm is more likely to increase its use of outside supply contracts in more competitive industries, as the coefficient for compete (TNIC) from Hoberg and Phillips (2010a) is strongly significant and positive. A firm is more likely to have higher use of outside supply contracts as well when its industry peers also highly use outside supply contracts, as the coefficient for high ind PO/COGS is significantly positive.

In the next four specifications, we report the estimated results of the firm-year panel regressions with a tobit and a linear probability model. Columns three and four, and column five and six of Table VII report the tobit and linear probability model estimation results respectively. In later regressions where we instrument for firm outsourcing intensity for each firm in each year, we use the firm-year level linear probability regression model from either column five or six of this table based on the fixed effects included.

Each of these specifications shows that the increase in a firm's outsourcing activity can be explained by whether the firm is closely located to a port of entry and how high its input transpiration costs are. The results also show that the percentage foreign tax paid by firms is significantly positively related to outsourcing intensity, as firms with higher foreign sales are more likely to use outside (foreign) supply contracts. Similar to the between-regression results in column one and two, firm growth measured by market to book value of equity and sales growth are significantly related to firm outsourcing intensity.

\subsection{Outsourcing and Leverage}

We now examine the relation between outsourcing and leverage and financing decisions. One might expect that given the decreased cash flow risk and increased flexibility on costs, outsourcing firms would have higher leverage and use more debt. We find the opposite result - leverage is lower for 
outsourcing firms. We show this finding is robust to using multiple different matching and regression based methods.

First, in TableVIII, we conduct a propensity score based matching model where we match outsourcing firms to non-outsourcing firms. Second, in subsequent tables we use panel regressions to examine the relation of leverage to outsourcing. In these tables we use the geographic variables from the previous table, Table VII. where we examine the propensity to outsource, to control for the endogeneity of the outsourcing decision.

In Table VIII, we compare the market leverage of the outsourcing firms to non-outsourcing firms using a propensity score matching model. Outsourcing firms are based on whether the firm has disclosed a non-zero amount of purchase obligations at the given fiscal year. The control observations are the 10 nearest neighbors across the matching variables within the same Hoberg and Phillips (2010a) FIC-25 industry group. The matching variables include $\log$ (mv assets), $\log$ (quarterly sales), $M / B$, operating margin, cash flow volatility, PPE/assets, \#patents/assets, and whether the firm operates in a high-tech industry.

\section{[INSERT TABLE VIII HERE]}

Table VIII shows that the leverage is lower for outsourcing firms in every quarter and significantly so in every quarter from the second quarter of 2007 to the last quarter of 2010. If we collapse over all quarters, leverage is significantly lower for outsourcing firms at the $2 \%$ level. This initial evidence shows that despite the lower cash flow volatility, outsourcing firms use less debt.

We now turn to examining the impact of outsourcing on leverage and financing decisions using multivariate panel regressions. We consider using both the actual amount of outsourcing and also instrumented outsourcing intensity. We instrument outsourcing intensity using the instrument "close to port" and "high transp cost" as described earlier. Both instruments should be valid instruments as they are important to the outsourcing decision and economically likely to satisfy the exclusion restriction as they should affect leverage only through the outsourcing channel.

Table IX presents the effect of outsourcing intensity on leverage in a regression framework. Our outsourcing variable is the lagged amount of the purchase obligations divided by cost of goods sold $(P O / C O G S)$. We report results using the instrumental variable approach with close to port and high transp cost as instruments for the lagged PO/COGS. 19 All the control variables from the outsourcing

\footnotetext{
${ }^{19}$ The uninstrumented OLS results are available from the authors. Results are qualitatively similar in all cases.
} 
intensity prediction regression (column five and six in Table VII are also included. In particular, we control for firm risk (cash flow volatility and stock return volatility) and the extent of the firm's characterizable assets through its property, plant and equipment (PPE/assets).

These control variables are important to rule out the possibility that our results are just coming from the effect of outsourcing firms greater risk such as exchange risk due to their possibly more extensive foreign trades, or the effect of reduced collateralizable assets. We also control for the percentage foreign tax paid by firms, as well as a firm's sales growth, operating margins and the market to book of a firm.

For the dependent variable, we begin with market leverage and move to more conservative measures, market leverage (with AP), and book leverage. market leverage (book leverage) is the ratio of total debt to the market (book) value of assets. Market value of total assets is market value of common equity plus book value of preferred stock plus debt (long-term debt + debt in current liabilities) plus book value of minority interest. For market leverage (with $A P$ ) in columns three and four we additionally include account payables as part of total debt to mitigate a concern that outsourcing firms are likely to have greater account payables which can be viewed as a substitute for debt 20 Other variable definitions are available in the Appendix.

In column one, three, and five of Table IX, we estimate the regression with industry and year fixed effects. We do not include firm fixed effects as the firms in our sample, over the limited time period we examine, do not change the geographic location of their main business location and thus our first stage regression has a strong firm-specific component. In column two, four, and six, we do not have industry or year fixed effects as we include variables that are time-invariant for each industry (the competition variable and high-tech industry dummy) and constant in a given year (the Aaa bond rate and the credit spread).

\section{[INSERT TABLE IX]HERE]}

Table IX] shows that outsourcing firms have significantly lower leverage in all specifications. Leverage decreases with predicted outsourcing intensity. These result hold for both market and book leverage, as well as leverage when we include accounts payables as part of debt. Our results show that there is a strong effect of outsourcing on leverage. Using the coefficients from the third column, we

\footnotetext{
${ }^{20}$ We present the main results with accounts payables included as debt in this table. For subsequent tables, we report regression results using this alternative leverage measure with account payables in the Appendix. Results are qualitatively similar in all cases.
} 
find that a one standard deviation increase in outsourcing intensity leads to a 0.051 standard deviation decrease in firm leverage. This economic effect is relatively greater than the effect of cash flow volatility, where a one standard deviation in cash flow volatility leads to a 0.022 standard deviation in firm leverage.

The table also shows that firms use more leverage when they have more fixed assets. A one standard deviation in property, plant and equipment (PPE/assets) leads to a 0.083 standard deviation increase in firm leverage. Thus, the effect of outsourcing (a 0.051 decrease) is comparable in magnitude to the effect of fixed assets. More importantly, given we control for fixed assets, our results are not just picking up a reduced collateral effect from the fact that outsourcing firms use less fixed assets.

The results are consistent with outsourcing firms using less debt to decrease the potential costs of financial distress on contracts with suppliers and employees. To consider this explanation more explicitly, we now explore if these effects are stronger for specific types of firms, in particular for firms with higher value added per employees and for firms with high R\&D suppliers who may place higher value on the low leverage of their customers.

\subsection{Value-Added and Human Capital}

We now explore in more detail why firms use less financial leverage when they outsource. The central idea we examine is whether firms will choose a financial structure that decreases the potential for bankruptcy when they have high value-added employees who are likely invest in firm specific human capital.

As Jaggia and Thakor (1994) model, higher financial leverage can decrease employees' incentives to invest more in firm-specific assets as a bankruptcy can cause the value of employee firm-specific assets to decrease. Thus, the firm will optimally take on a lower amount of debt to counteract the effect of bankruptcy on an employee's incentive to invest in human capital. The reasoning is that an increase in the probability of bankruptcy lessens the likelihood that long-term wage commitments will be honored ex post and imposes a cost on the firm and its employees with greater specificity. Such a firm, therefore, is predicted to optimally take on a lower amount of debt.

The model of Berk, Stanton, and Zechner (2010) shows that even without firm-specific human capital, more human-capital intensive firms will have less financial leverage as the optimal contract involves firms providing a more stable fixed compensation contract when employees are averse with respect to their human capital. 
We explore these arguments in Table $\mathrm{X}^{21}$ Specifically, we examine if firms in industries with high value-added per worker have less leverage, when they outsource more and use outside purchase contracts. In order to examine the potential for high value-added employees and firms to invest in relationship specific assets, we also include a measure of whether the industry has high R\&D activity, which is a potential indicator for asset specificity.

The hypothesis is that financial leverage of outsourcing firms should be lower in industries with high value added per employee and high $R \& D$ as it is in these industries that there are high potential costs of financial distress on employees and contracting parties that may have firm-specific human capital and relationship-specific investment.

\section{[INSERT TABLE X] HERE]}

The first column of $\mathrm{X}$ shows that outsourcing firms that produce in industries with high value added per employee use less book leverage as both the instrumented purchase obligation coefficient and the coefficient on the interaction between purchase obligations and high value-added industry indicator are negative (significantly negative for the coefficent on the interaction variable).

In column two and three, we explore these effects further with partitioning the sample by high versus low industry R\&D intensity. The increased significance for the negative coefficient of the interaction term indicates that firms that are in high value-added per employee, high R\&D industries have less leverage. This result in particular is consistent with outsourcing firms choosing less financial leverage to mitigate the potential human capital loss by high value-added employees. In these industries it is likely that there is the greatest potential for firm-specific human capital investment and thus the greater value for outsourcing firms to choose lower leverage to mitigate any expected losses. In contrast, firms in the low R\&D industries do not show the more pronounced outsourcing effect even when they operate in high value-added per employee industries.

We examine the same arguments in column four to six using market leverage. By examining both book and market leverage results, we show that the strong effect of outsourcing on leverage does not just come from the effect on book leverage. Overall, the results support the conclusion that outsourcing firms use less leverage when they operate in industries where employees are more likely to make human capital investments.

\footnotetext{
${ }^{21}$ Appendix Table A1 shows similar results when we include accounts payables as part of leverage.
} 


\subsection{Outsourcing and the Characteristics of Suppliers}

In this section we examine the how the impact of outsourcing on the leverage of firms varies with the characteristics of suppliers. We ask to what extent supplier characteristics affect how outsourcing impacts leverage given there is the potential for relationship-specific investment by supplier firms as well. We consider those cases where we are able to identify the exact suppliers with which the firm is doing business. In Table $\mathrm{XI}^{22}$ we focus two different aspects of suppliers; R\&D intensity of suppliers and the total number of suppliers. We include supplier labor intensity in our regression analysis along with the percentage of the suppliers that are from outside of the U.S. and the percentage of the suppliers in the manufacturing sector. We also include an indicator variable that identifies that the supplier is producing in a concentrated industry and the relative size of suppliers versus their customers, to control for the potential that the firm uses less leverage in situations where it needs to increase its bargaining power vis-a-vis its suppliers as in Kale and Shahrur (2007).

In columns one to three in Table XI, we first interact the outsourcing variable with a measure of supplier R\&D intensity to examine if the firm uses less leverage when it is dealing with suppliers who need to invest in R\&D so as to provide more assurance of their safety. As each supplier's SIC code is available from the Capital IQ supplier data and not the supplier's actual R\&D, we use the 3-digit industry median of R\&D/sales from Compustat for each supplier's R\&D intensity variable. high supp $R \& D$ in the table is a firm-level dummy variable that equals one if the average supplier R\&D intensity of a given firm is in the highest tercile of the sample.

\section{[INSERT TABLE XI HERE]}

The results in Table XI show that firms use less leverage when their suppliers have higher R\&D intensity. This result is consistent with outsourcing firms using less leverage when they contract with high R\&D suppliers who may place higher value on the low leverage of their customers. In column two and three, we explore the same argument further partitioning the sample by high versus low industry R\&D intensity. The result show that the significance of the negative effect of outsourcing on leverage increases when both the customer and supplier are R\&D intensive.

In column four to six in Table XI, we interact the outsourcing variable with the total number of suppliers variable. The results show that the number of supplier is negatively associated with the firm's leverage. If one views the number of suppliers as a measure of firm bargaining power vis-a-vis

\footnotetext{
${ }^{22}$ Appendix Table A2 shows similar results when we include accounts payables as part of leverage.
} 
its suppliers, this result is not consistent with firms using leverage when they have more bargaining power. It is consistent with the firm using less financial leverage to reduce the probability of financial distress and bankruptcy when it signs more contracts externally, to mitigate the loss of relationship specific assets created with external contracting. The effect of the interaction term only gets stronger, when the outsourcing firms are in high $\mathrm{R} \& \mathrm{D}$ industries (column five).

Overall, the results are in particular consistent with outsourcing firms choosing less financial leverage to mitigate the potential loss of suppliers' relationship-specific investments with greater asset specificity.

\subsection{Outsourcing and Security Issuance}

In this section, we examine security issuance decisions directly. This section avoids the problem of changes in leverage that are driven by stock market movements or accounting changes. The hypothesis is that outsourcing affects not only equity versus debt financing, but also whether the firm raises capital in the public versus the private markets. We examine firm security issuance decisions using both a multinomial and a nested logit framework. We consider six different security types: public and private debt, public and private convertibles, and public and private equity. We begin with the multinomial framework where each alternative is independent of the other alternatives. This assumption is called independence of irrelevant alternatives (IIA) and while strong, allows us to present initial evidence. We relax this assumption in the subsequent table when we estimate a nested logit model.

Table XII presents coefficient estimates from the multinomial logistic regression testing the impact of outsourcing intensity on public and private security issues. The dependent variable is the relative log-odds of issuing each security type vs. the base choice of public debt. PO/COGS (instr.) is the outsourcing intensity instrumented using the variable close to port and high transp costs. Industry and year control variables are included, but not reported.

\section{[INSERT TABLE XII HERE]}

Table XII shows that outsourcing intensity significantly increases the probability of issuing public equity over public debt. In addition, we see that the probability of choosing private debt over public debt is significantly greater than zero. The results also show that riskier firms are more likely to choose other securities over public debt and that firms with a higher marginal tax rate are more likely to issue private debt. Overall, the results indicate that firms with outside purchase obligations choose more flexible financial structure, consistent with their financial structure being influenced by firm 
contracting with their own employees and suppliers in order to maintain their incentives to invest in relationship-specific assets.

We now examine security issuance using a nested logit approach. This approach allows correlation in the errors within the public versus private choice of market, and also allows correlation in the errors for the type of security - debt, convertibles, and equity - within the public or private market choice. The interpretation of this structure is that firms' choices of security type are correlated within markets (public versus private). Tests indicate that the assumption of IIA within each market is not rejected. Thus, unobserved factors affect security choice conditional on the market, causing errors to be correlated across securities within markets.

Table XIII presents the coefficient estimates from the nested logit regression testing the impact of outsourcing intensity on public and private security issues. The table presents the choice of market (private versus public) in the first column and the type of securities (equity or convertible verses debt) within markets in columns two through five. PO/COGS (instr) is the predicted outsourcing intensity using close to port and high transp cost as instruments for PO/COGS. All control variables are the same as the outsourcing intensity prediction regression (column six in Table VII). Industry and year control variables are included, but not reported.

\section{[INSERT TABLE XIII HERE]}

Examining the results presented in Table XIII, we can see that the coefficient on instrumented outsourcing intensity significantly impacts the private versus public market choice. Firm outsourcing intensity increases the probability of firms choosing to issue securities in the private market over the public market. Within markets, the choices show that outsourcing firms avoid issuing debt significantly so for the choice of issuing public convertibles over public debt. The results indicate that firms with outside purchase contracts choose to issue in private market, consistent with these firms choosing securities that give them more flexibility and lower risk. Overall, the results are consistent with a desire to reduce the probability that employees and suppliers will suffer a loss in their human and firm-specific capital.

\section{Conclusions}

We examine the impact of supplier contracting on firm risk and capital structure using a unique database of external purchase agreements. We analyze the hypothesis that incomplete contracting 
between firms and their suppliers and employees affects how firms finance their operations. We thus extend the extensive incomplete contracting literature that begins with Grossman and Hart (1986) and Hart and Moore (1990) by showing that incomplete contracting affects not just the vertical integration decision but also the financing decisions of firms in contracting relationships with suppliers and employees.

We document that firm outsourcing through purchase agreements is associated with a reduction in firm cash flow volatility relative to matched non-outsourcing firms, in particular during the recent financial crisis. During the recent financial crisis, outsourcing firms were able to better match costs with sales fluctuations, as firms that use supply contracts incur fewer fixed costs thus reducing their operating leverage.

Despite the reduction in cash flow volatility, we document that outsourcing firms use less financial leverage. We show that these firms use less debt when they operate in high R\&D, high value-added per worker industries. We take into account the fact that the outsourcing decision is itself an endogenous decision. We instrument for the outsourcing decision using the geographic location of the firm, specifically how close it is to major ports, airports or border crossings and the transportation costs of its inputs.

Examining actual firm supplier data, we find that high R\&D intensity of suppliers and the number of suppliers are negatively associated with own firm leverage. If one views the number of suppliers as a measure of firm bargaining power vis-a-vis its suppliers, this result is not consistent with firms using leverage when they have more bargaining power. These results are consistent with the firm using less financial leverage to reduce the probability of financial distress and bankruptcy when it signs more contracts externally to mitigate the expected losses distress might cause on relationship-specific assets created with external contracting.

Examining security issuance by firms, we document that outsourcing firms are more likely to issue equity and more private securities when they issue financial securities. We find that when outsourcing firms do issue debt, they choose private debt over public debt. These results show that outsourcing firms choose more flexible securities that can be more easily renegotiated. In our context of separate ownership with outside supply contracts, our results indicate that outsourcing firms with high valueadded employees choose more flexible capital structures through the use of more equity-based and private securities.

These findings are consistent with outsourcing firms choosing a capital structure that increases their flexibility in order to reduce the costs of financial distress on high value added employees and 
thus to increase the incentives of contracting firms to invest in relationship-specific assets. Overall, the results are consistent with incomplete contracting between firms and their suppliers and employees affecting not only who should own the assets, but also how firms should finance their assets. 


\section{Appendix A Semiconductor Firms and Outside Purchase Strategies}

This appendix presents three examples of firms operating in the semiconductor industry with different outsourcing strategies. It shows their purchase obligations and their financial leverage over time. Fairchild Semiconductor owns continuously operating semiconductor manufacturing facilities, while Marvell Technology Group is a leading fabless semiconductor company. Xilinx has changed its outside purchase obligations over time. $P O$ is the total amount of purchase obligations due within the next fiscal year. $P O / C O G S$ is the total amount of purchase obligations scaled by cost of goods sold. book (market) leverage is the book value of debt scaled by the book (market) value of total assets.

\begin{tabular}{|c|c|c|c|c|c|c|}
\hline year & sales (\$million) & PO (\$million) & PO/COGS & CAPX/sales & book leverage & market leverage \\
\hline \multicolumn{7}{|c|}{ FAIRCHILD SEMICONDUCTOR INTERNATIONAL INC } \\
\hline 2004-2010 & 1529.8 & 84.2 & 0.087 & 0.092 & 0.284 & 0.236 \\
\hline 2004 & 1601.0 & 77.9 & 0.077 & 0.138 & 0.357 & 0.274 \\
\hline 2005 & 1425.1 & 125.9 & 0.128 & 0.062 & 0.335 & 0.219 \\
\hline 2006 & 1651.1 & 123.8 & 0.117 & 0.080 & 0.290 & 0.199 \\
\hline 2007 & 1670.2 & 79.9 & 0.074 & 0.086 & 0.276 & 0.218 \\
\hline 2008 & 1574.2 & 28.5 & 0.028 & 0.104 & 0.289 & 0.383 \\
\hline 2009 & 1187.5 & 52.2 & 0.070 & 0.039 & 0.268 & 0.239 \\
\hline 2010 & 1599.7 & 100.9 & 0.112 & 0.133 & 0.173 & 0.122 \\
\hline \multicolumn{7}{|c|}{ MARVELL TECHNOLOGY GROUP LTD } \\
\hline 2004-2010 & 2485.3 & 230.3 & 0.217 & 0.052 & 0.029 & 0.013 \\
\hline 2004 & 1224.6 & 104.0 & 0.193 & 0.056 & 0.009 & 0.003 \\
\hline 2005 & 1670.3 & 224.5 & 0.312 & 0.080 & 0.012 & 0.002 \\
\hline 2006 & 2237.6 & 457.0 & 0.403 & 0.108 & 0.096 & 0.036 \\
\hline 2007 & 2894.7 & 279.0 & 0.180 & 0.051 & 0.088 & 0.049 \\
\hline 2008 & 2950.6 & 62.6 & 0.046 & 0.025 & 0.001 & 0.001 \\
\hline 2009 & 2807.7 & 213.3 & 0.187 & 0.013 & 0.000 & 0.000 \\
\hline 2010 & 3611.9 & 271.5 & 0.198 & 0.032 & 0.000 & 0.000 \\
\hline \multicolumn{7}{|c|}{ XILINX INC } \\
\hline 2004-2010 & 1858.8 & 89.2 & 0.141 & 0.035 & 0.172 & 0.067 \\
\hline 2004 & 1573.2 & 97.2 & 0.185 & 0.044 & 0.000 & 0.000 \\
\hline 2005 & 1726.3 & 76.8 & 0.127 & 0.043 & 0.000 & 0.000 \\
\hline 2006 & 1842.7 & 59.1 & 0.089 & 0.064 & 0.314 & 0.111 \\
\hline 2007 & 1841.4 & 74.3 & 0.117 & 0.025 & 0.319 & 0.123 \\
\hline 2008 & 1825.2 & 46.5 & 0.076 & 0.021 & 0.244 & 0.108 \\
\hline 2009 & 1833.6 & 129.5 & 0.208 & 0.015 & 0.111 & 0.044 \\
\hline 2010 & 2369.4 & 141.3 & 0.184 & 0.035 & 0.215 & 0.086 \\
\hline
\end{tabular}




\section{Appendix B Collection of Purchase Obligations Data}

This appendix describes how we collect the purchase obligations data. We first electronically gather all "10-K"s and "10-K405"s by PERL web crawling 23 of the SEC Edgar database, searching for the filings from 2004 to 2010. We do not include "10KSB"s and "10KSB40"s, because small business issuers (or smaller reporting companies) are not required to disclose purchase obligations by the SEC's final rules. Then, using PERL programming we specifically extract purchase obligations data in the MD\&A section and other identifying information including the CIK number in each 10-K.

There are two types of reporting practices. First, firms use HTML documents. In this case, purchase obligations are disclosed in tabular formats. Second, firms use TEXT documents. In this case, it is highly likely that the firms disclose purchase obligations also in textual formats. For the HTML groups, we extract all tables first and then sort out the certain tables including search keywords. The search keywords are the combinations of "purchase" and one of the following terms: "obligation" "commitment", "agreement", "order" or "contract". From the tables including the search terms, we extract the proper rows that contain the amount of purchase

obligations. For the TEXT document group, we use page breaks instead of tables. From the pages including the above search terms, we extract the proper sentences that contain information on the amount of purchase obligations.

In the event that the extraction process cannot sort out a table or a page containing search terms, we reexamine the whole document and search for another terms including either "contract obligation" or "contract commitment". When the extracted information does not contain "purchase" or there still exists no match for the search terms, we conclude that the firm has no purchase obligations.

The reporting units vary with reporting firms. Therefore, we normalize the units of disclosed purchase obligations in million dollars, by matching other information in the extracted tables or pages with the corresponding Compustat data item.

\footnotetext{
${ }^{23}$ We acknowledge that Andy Leone's Perl resource page at http://sbaleone.bus.miami.edu/PERLCOURSE/Perl_Resources.html provides a useful help to get started Edgar web crawling algorithms using PERL.
} 


\section{Appendix C Variable Definitions}

- PO ever exists is the firm-level variable that equals one, if a given firm has disclosed a non-zero amount of purchase obligations at least once during the sample period.

- $P O$ exists is the firm-level variable that equals one, if a given firm has disclosed a non-zero amount of purchase obligations in the given year.

- $P O / C O G S$ is the total amount of purchase obligations due within the next fiscal year, scaled by cost of goods sold.

- $\log (m v$ assets) is the log of market value of the firm's assets. Market value of assets is market value of common equity plus book value of preferred stock plus debt (long-term debt + debt in current liabilities) plus book value of minority interest.

- NYSE size pct is the percentile of the firm's market cap, based on Fama-French's NYSE breakpoints.

- $\log (1+a g e)$ is the log of one plus firm age, defined as a given year minus the year when the firm first appeared in Compustat.

- $M / B$ is market value of assets divided by book value of assets.

- $R O A$ is net operating income divided by total assets in the prior year.

- $R O S$ or operating margin is operating income before depreciation, scaled by sales.

- $R \mathcal{E} D /$ sales is $\mathrm{R} \& \mathrm{D}$ expenditures divided by sales in the prior year.

- cash/assets is cash and short-term investments divided by assets.

- market leverage is the ratio of total debt to the market value of assets.

- market leverage (with AP) additionally includes account payables as part of total debt.

- book leverage is the ratio of total debt to the book value of assets.

- emp/sales is the number of employees divided by sales. (persons/million dollar)

- $P P E /$ assets is gross property, plant and equipment divided by total assets in the prior year.

- $C A P X /$ sales is capital expenditures divided by sales in the prior year.

- sales growth is the percentage growth in sales in a given year.

- \#patent/assets is the total patent count granted to the firm during the 20 year period from 1985 to 2004, scaled by the average total assets during the period. Under the current U.S. patent laws, the term of a patent is 20 years from the filing date of the earliest application.

- cash flow volatility or $S D$ (operating margin) is the standard deviation of operating margin from the previous 12 quarters.

- $S D(R O A)$ is the standard deviation of $R O A$.

- abnormal stock return is the estimated stock alpha from a regression of the firm's daily excess stock returns (raw returns minus the risk-free rate) in the prior 252 trading days (over the one fiscal year period from June to May in the next year) using the market model. Results do not change by using the Fama French 3 or 4 factor models.

- stock return volatility is the log of standard deviation of the firm's daily logarithmic returns over the 252 trading days starting from June to May in the next year, multiplied by the square root of the time period, 252 .

- default probability is Merton's naive default probability (distant to default) based on the approach in Bharath and Shumway (2008). Refer to our Empirical Strategy and Variables of Interest section and Bharath and Shumway (2008) for the detailed explanation on how to construct this measure.

- demand shock is the detrended annual percentage change in the downstream industry demands using the 2002 input-output benchmark table from the Bureau of Economic Analysis, following Maksimovic and Phillips (2001). To detrend this variable, we regress it on industry and year fixed effects indicator variables and then take the residual from this regression. The downstream industry demands data come from the chain-type quantity indexes for gross output by industry from the U.S. Department of Commerce's Bureau of Economic Analysis. For the consumer and government demands, we use personal consumption indexes and government spendings and investment indexes. 
- negative demand shock is a discretized version of demand shock, which equals one when demand shock is negative and zero otherwise.

- Aaa bond rate is the Aaa corporate bond yield.

- credit spread: Baa-Aaa is the spread between the Baa and Aaa corporate bond yields.

- compete (TNIC) is one minus the TNIC Herfindahl index. The TNIC Herfindahl index is a measure of product market competitiveness based on the Text-Based Network Industries by Hoberg and Phillips (2010a).

- high-tech industry is a dummy variable indicating the 31 four-digit SIC code industries defined as high technology manufacturing industries by TechAmerica organization. By high-technology, we refer to microelectronics rather than other technologies. We do not include bio-technology firms in the high-tech industries, as biotechnology is not established yet with its own set of SIC codes and rather widely spreads over the drug sectors. Our high-tech industry classification is compatible with Loughran and Ritter (2004) classification.

- value added/employee (VAE) is operating income before depreciation divided by the number of employees in the prior year. This equals zero when operating income before depreciation is negative.

- ind VAE is the median value added/employee (VAE) in each FIC-25 code industry by Hoberg and Phillips (2010a).

- high ind VAE is an industry-level dummy variable that equals one if the given industry's value added per employee (VAE) is greater than the sample median.

- high ind REDD is an industry-level dummy variable that equals one if the given industry's R\&D/sales is in the highest tercile of the sample.

- high ind $P O / C O G S$ is an industry-year level dummy variable that equals one if a given industry's mean $\mathrm{PO} / \mathrm{COGS}$ level is greater than the median of all industries in the sample at the given year.

- high supp $R \mathscr{E} D$ is a firm-level dummy variable that equals one if the average $\mathrm{R} \& \mathrm{D}$ intensity (R\&D/sales) of the firm's suppliers is in the highest tercile of the sample. The CapitalIQ database tracks each supplier firm's SIC code even for foreign or private supplier firms, but does not report their R\&D expenditures. Thus, the median R\&D intensity of U.S. public firms within the same SIC code group as the supplier is used to approximate the supplier's R\&D intensity.

- high supp labor is a firm-level dummy variable that equals one if the average labor intensity (number of employees divided by sales) of the firm's suppliers is in the highest tercile of the sample.

- high supp \# is a firm-level dummy variable that equals one if the firm's total number of suppliers is in the highest tercile of the sample

- high \% foreign supp is a firm-level dummy variable that equals one if the percentage of the foreign suppliers out of all suppliers is in the highest tercile of the sample

- relative supp size small is a firm-level dummy variable that equals one if the average sales of a given firm's suppliers relative to the firm's own sales is in the lowest tercile of the sample.

- high supp HHI is a dummy variable that equals one if the average HHI of the firm's suppliers (based on the TNIC Herfindahl index by Hoberg and Phillips (2010a)) is in the highest tercile.

- \% manufacturing supplier is the percentage of the suppliers in the manufacturing sector.

- \% foreign tax is the percentage foreign income tax paid out of total income tax paid in each fiscal year.

- marginal tax rate is a firm's marginal tax rate kindly provided to us by John Graham. The marginal tax rate after deductions for depreciation, interest and leasing expenses is used. 


\section{References}

Agrawal, Ashwini, and David A. Matsa, forthcoming 2013, Labor Unemployment Risk and Corporate Financing Decisions, Journal of Financial Economics.

Allen, Jeffrey W., and Gordon M. Phillips, 2000, Corporate Equity Ownership, Strategic Alliances and Product Market Relationships, Journal of Finance 55, 2791-2815.

Antras, Pol, forthcoming, Grossman Hart (1986) Goes Global: Incomplete Contracts, Property Rights, and the International Organization of Production, Journal of Law, Economics, and Organization.

Baker, George P., and Thomas N. Hubbard, 2004, Contractibility and Asset Ownership: On-Board Computers and Governance in U. S. Trucking, Quarterly Journal of Economics 119, 1443-1479.

Berk, Jonathan B., Richard Stanton, and Josef Zechner, 2010, Human Capital, Bankruptcy, and Capital Structure, Journal of Finance 65, 891-926.

Bharath, Sreedhar T., and Tyler Shumway, 2008, Forecasting default with the Merton distance to default mode, Review of Financial Studies 21, 1339-1369.

Bolton, Patrick, and David S. Scharfstein, 1996, Optimal Debt Structure and the Number of Creditors, Journal of Political Economy 104, 1-25.

Brown, Jennifer, and David A. Matsa, 2013, Boarding a Sinking Ship? An Investigation of Job Applications to Distressed Firms, Working Paper, Northwestern University.

Chava, Sudheer, and Michael R. Roberts, 2008, How Does Financing Impact Investment? The Role of Debt Covenants, Journal of Finance 63, 2085-2121.

Fee, C. Edward, Charles J. Hadlock, and Shawn Thomas, 2006, Corporate Equity Ownership and the Governance of Product Market Relationships, Journal of Finance 61, 12171251.

Fort, Teresa, 2011, Breaking Up Is Hard To Do: Why Firms Fragment Production Across Locations, Working Paper.

Gavazza, Alessandro, 2011, Leasing and secondary markets: theory and evidence from commercial aircraft, Journal of Political Economy 119, 325-377.

Giroud, Xavier, 2012, Proximity and investment: Evidence from plant-level data, Quarterly Journal of Economics p. forthcoming.

Gomes, Armando, and Gordon Phillips, 2012, Why do public firms issue private and public securities?, Journal of Financial Intermediation 21, 619658.

Graham, John, 1996, Debt and the Marginal Tax Rate, Journal of Financial Economics.

Grossman, Sanford J., and Oliver D. Hart, 1986, The Costs and Benefits of Ownership: A Theory of Vertical and Lateral Integration, Journal of Political Economy 94, 691-719.

Handfield, Robert, 1994, U.S. Global Sourcing: Patterns of Development, International Journal of Operations and Production Management 14, 40-51.

Hart, Oliver, and John Moore, 1990, Property Rights and the Nature of the Firm, Journal of Political Economy 98, 1119-1158.

Helpman, Elhanan, 2006, Trade, FDI, and The Organization Of Firms, Journal of Economic Literature $44,589-630$. 
Hoberg, Gerard, and Gordon Phillips, 2010a, Text-based network industry classifications and endogenous product differentiation, University of Maryland Working Paper.

Hsu, Scott H. C., Adam V. Reed, and Jorg Rocholl, 2012, Competitive Effects of Private Equity Investments, Working Paper.

Huang, Rongbing, and Jay R. Ritter, 2009, Testing Theories of Capital Structure and Estimating the Speed of Adjustment, Journal of Financial and Quantitative Analysis 44, 237-271.

Jaggia, Priscilla Butt, and Anjan V. Thakor, 1994, Firm-Specific Human Capital and Optimal Capital Structure, International Economic Review 35, 283-308.

Kale, Jayant R., and Husayn Shahrur, 2007, Corporate capital structure and the characteristics of suppliers and customers, Journal of Financial Economics 83, 321-365.

Lee, Kwang J., 2010, Purchase Obligations, Earnings Persistence and Stock Returns, Working Paper.

Lerner, Josh, Morten Sorensen, and Per Stromberg, 2011, Private equity and long-run investment: The case of innovation, Journal of Finance 66, 445-477.

Levy, David L., 1995, International Sourcing and Supply Chain Stability, Journal of International Business Studies 26, 343-360.

Loughran, Tim, and Jay Ritter, 2004, Why has ipo underpricing changed over time?, Financial Management $33,5-37$.

Maksimovic, Vojislav, and Gordon Phillips, 2001, The market for corporate assets: Who engages in mergers and asset sales and are there efficiency gains?, Journal of Finance 56, 2019-2065.

Merton, Robert C., 1974, On the pricing of corporate debt: the risk structure of interest rates, Journal of Finance 29, 449-470.

Monczka, Robert M., and Robert J. Trent, 2003, International Purchasing and Global Sourcing - What are the Differences?, Journal of Supply Chain Management 39, 26-36.

Moon, S. Katie, 2012, Firm Risk Taking versus CEO Diversification: Evidence from Outsourcing Firms, Working Paper.

Nunn, Nathan, and Daniel Trefler, 2012, Incomplete Contracts and the Boundaries of the Multinational Firm, Journal of Economic Behavior and Organization.

Phillips, Gordon, and Giorgo Sertsios, 2012, How Do Firm Financial Conditions Affect Product Quality and Pricing?, Management Science Forthcoming.

Plambeck, Erica L., and Terry A. Taylor, 2005, Sell the Plant? The Impact of Contract Manufacturing on Innovation, Capacity, and Profitability, Management Science 51 133-150.

Spencer, Barbara J., 2005, International Outsourcing And Incomplete Contracts, Canadian Journal of Economics 38, 1107-1135.

Stromberg, Per, 2008, The New Demography of Private Equity, Working Paper.

Williams, Ryan, 2012, Vertical firm boundaries: supplier-customer contracts and vertical integration, Working Paper.

Williamson, Oliver E., 1979, Transaction-Cost Economics: The Governance of Contractual Relations, Journal of Law and Economics 22, 112-123. 


\begin{tabular}{|c|c|c|c|c|c|}
\hline & Total & $\begin{array}{c}\text { Payments } \\
\text { Due in Less } \\
\text { Than } \\
1 \text { vear } \\
\end{array}$ & $\begin{array}{c}\text { Payments } \\
\text { Due in } \\
1-3 \text { years }\end{array}$ & $\begin{array}{c}\text { Payments } \\
\text { Due in } \\
\text { 4-5 years } \\
\end{array}$ & $\begin{array}{c}\text { Payments } \\
\text { Due in More } \\
\text { Than } \\
5 \text { years } \\
\end{array}$ \\
\hline Operating Leases & $\$ 865$ & $\$ 108$ & $\$ 211$ & $\$ 192$ & $\$ 354$ \\
\hline Purchase Obligations & 1,994 & 1,994 & - & - & - \\
\hline Asset Retirement Obligations & 14 & - & 2 & 2 & 10 \\
\hline Other Obligations & 4 & 4 & - & - & - \\
\hline Total & $\$ 2,877$ & $\overline{\$ 2,106}$ & $\$ 213$ & $\$ 194$ & $\$ 364$ \\
\hline
\end{tabular}

(a) Source: Apple Inc.'s 10-K for the fiscal year 2005

\begin{tabular}{|c|c|c|c|c|c|c|c|c|c|}
\hline \multirow[b]{2}{*}{ Operating leases } & Total & \multicolumn{2}{|c|}{$\begin{array}{c}\text { Payments Due } \\
\text { in Less } \\
\text { Than } 1 \text { Year }\end{array}$} & \multicolumn{2}{|c|}{$\begin{array}{c}\text { Payments } \\
\text { Due in } \\
\text { 1-3 Years }\end{array}$} & \multicolumn{2}{|c|}{$\begin{array}{c}\text { Payments } \\
\text { Due in } \\
\text { 4-5 Years } \\
\end{array}$} & \multicolumn{2}{|c|}{$\begin{array}{c}\text { Payments Due } \\
\text { in More } \\
\text { Than } 5 \text { Years } \\
\end{array}$} \\
\hline & $\overline{\$ 1,760}$ & $\overline{\$}$ & 195 & $\overline{\$}$ & 409 & $\overline{\$}$ & 368 & $\overline{\$}$ & 788 \\
\hline Purchase obligations & 5,378 & & 5,378 & & - & & - & & - \\
\hline Asset retirement obligations & 28 & & - & & 8 & & 7 & & 13 \\
\hline Other obligations & 471 & & 242 & & 124 & & 105 & & - \\
\hline Total & $\$ 7,637$ & $\$$ & 5,815 & $\$$ & 541 & $\$$ & 480 & $\$$ & 801 \\
\hline
\end{tabular}

(b) Source: Apple Inc.'s 10-K for the fiscal year 2008

Figure 1: Examples of Purchase Obligations Disclosures

Description of purchase obligations excerpted from the footnotes of Apple Inc.'s 2008 10-K: "The Company utilizes several contract manufacturers to manufacture sub-assemblies for the Company's products and to perform final assembly and test of finished products. These contract manufacturers acquire components and build product based on demand information supplied by the Company, which typically covers periods ranging from 30 to 150 days. The Company also obtains individual components for its products from a wide variety of individual suppliers. Consistent with industry practice, the Company acquires components through a combination of purchase orders, supplier contracts, and open orders based on projected demand information. Such purchase commitments typically cover the Company's forecasted component and manufacturing requirements for periods ranging from 30 to 150 days. In addition, the Company has an off-balance sheet warranty obligation for products accounted for under subscription accounting pursuant to SOP No. 97-2 whereby the Company recognizes warranty expense as incurred. As of September 27, 2008, the Company had outstanding off-balance sheet third-party manufacturing commitments, component purchase commitments, and estimated warranty commitments of $\$ 5.4$ billion. During 2006 , the Company entered into long-term supply agreements with Hynix Semiconductor, Inc., Intel Corporation, Micron Technology, Inc., Samsung Electronics Co., Ltd., and Toshiba Corporation to secure supply of NAND flash memory through calendar year 2010. As part of these agreements, the Company prepaid $\$ 1.25$ billion for flash memory components during 2006, which will be applied to certain inventory purchases made over the life of each respective agreement. The Company utilized $\$ 567$ million of the prepayment as of September 27, 2008." 


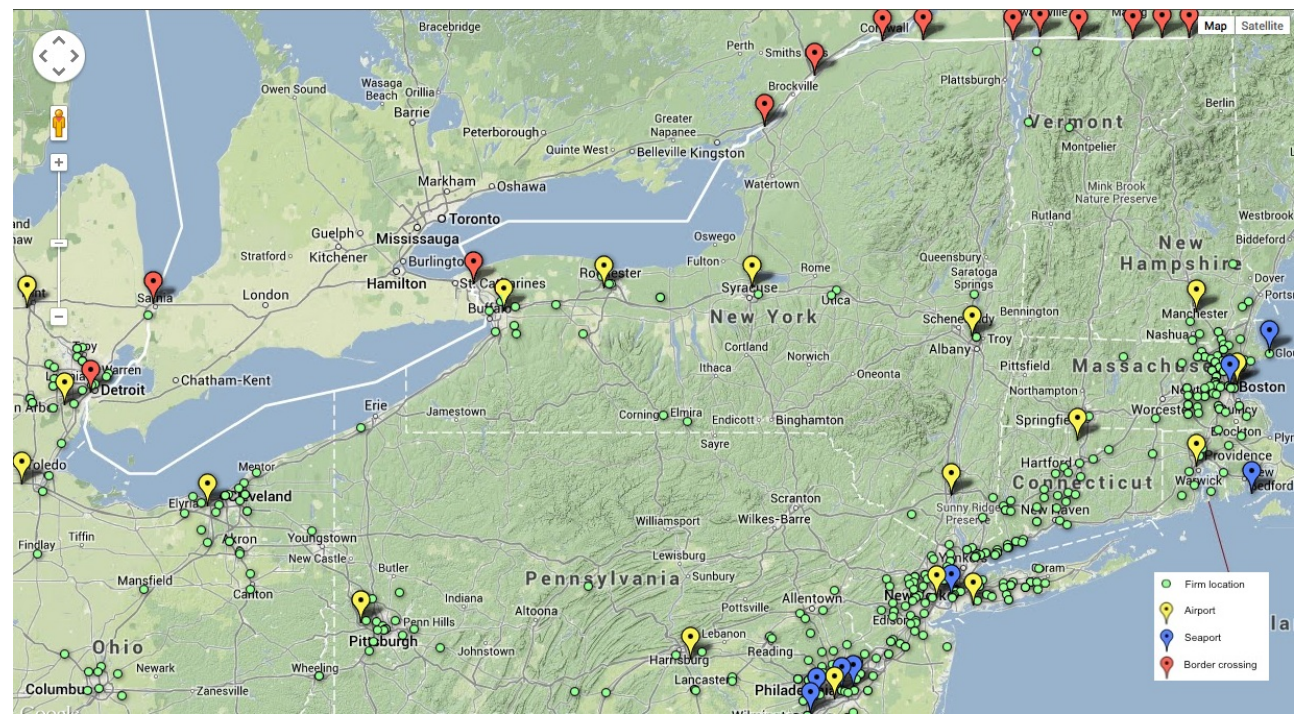

(a) East Coast Region

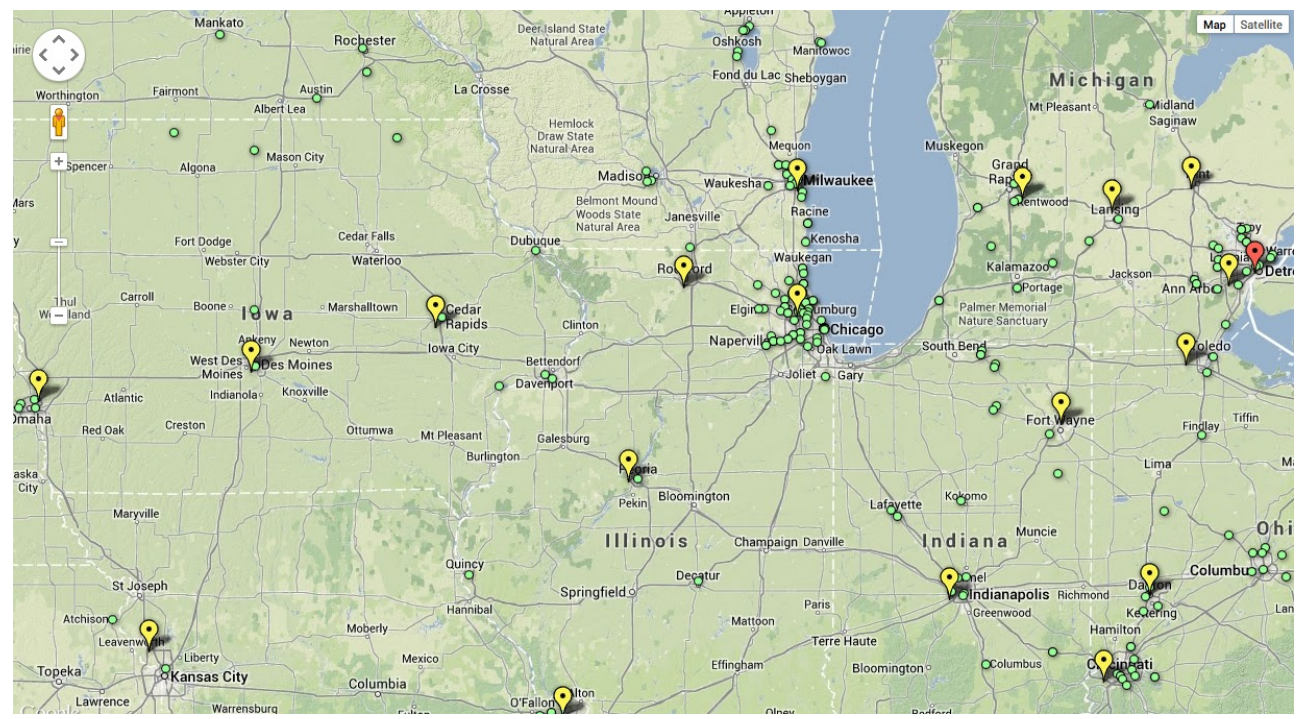

(b) Midwest Region

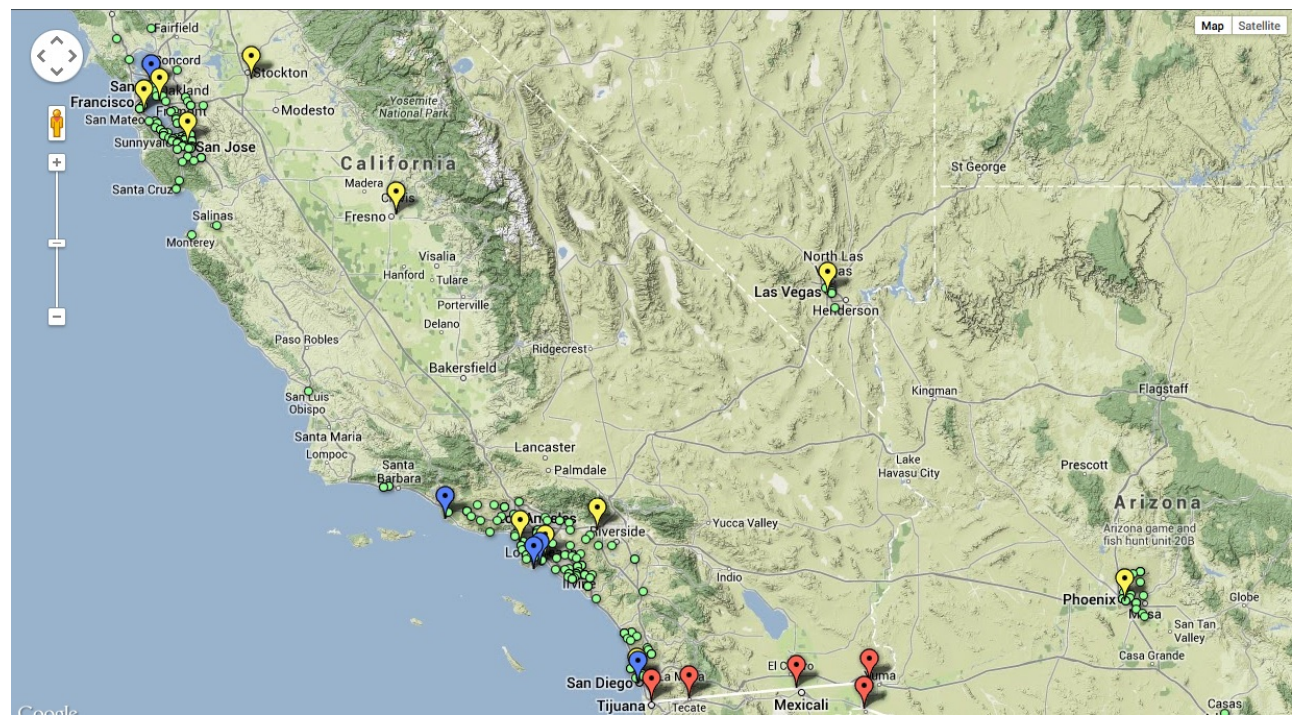

(c) West Coast Region

Figure 2: Firm Main Business Locations and U.S. Major Ports of Entry 
Table I: Descriptive Statistics of Outsourcing Activity by Industry

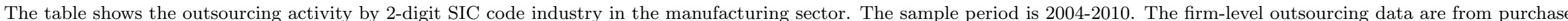

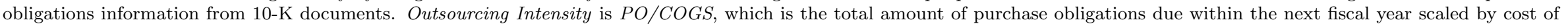
goods sold. PO/COGS is winsorized at the top and bottom $1 \%$ of the distribution.

\begin{tabular}{|c|c|c|c|c|c|c|}
\hline \multirow[b]{2}{*}{ Industry Description } & \multirow[b]{2}{*}{$\begin{array}{l}\text { SIC } \\
\text { Code }\end{array}$} & \multirow[b]{2}{*}{$\begin{array}{c}\text { Total } \\
\text { Firms }(\#)\end{array}$} & \multirow[b]{2}{*}{$\begin{array}{l}\text { Outsourcing } \\
\text { Firms }(\#)\end{array}$} & \multirow[b]{2}{*}{$\begin{array}{l}\text { Outsourcing } \\
\text { Firms }(\%)\end{array}$} & \multirow[b]{2}{*}{$\begin{array}{l}\text { Outsourcing } \\
\text { Intensity }\end{array}$} & \multirow{2}{*}{$\begin{array}{c}\text { Outsourcing Firms Only } \\
\text { Outsourcing } \\
\text { Intensity }\end{array}$} \\
\hline & & & & & & \\
\hline Food and kindred products & 20 & 83 & 59 & 0.711 & 0.091 & 0.128 \\
\hline Tobacco manufactures & 21 & 6 & 6 & 1 & 0.169 & 0.169 \\
\hline Textile mill products & 22 & 12 & 8 & 0.667 & 0.022 & 0.033 \\
\hline Apparel and other textile products & 23 & 39 & 23 & 0.59 & 0.121 & 0.204 \\
\hline Lumber and wood products & 24 & 16 & 6 & 0.375 & 0.008 & 0.022 \\
\hline Furniture and fixtures & 25 & 24 & 13 & 0.542 & 0.032 & 0.059 \\
\hline Paper and allied products & 26 & 39 & 30 & 0.769 & 0.053 & 0.068 \\
\hline Printing and publishing & 27 & 46 & 26 & 0.565 & 0.02 & 0.036 \\
\hline Chemicals and allied products & 28 & 343 & 239 & 0.697 & 0.126 & 0.181 \\
\hline Petroleum and coal products & 29 & 22 & 19 & 0.864 & 0.114 & 0.132 \\
\hline Rubber and miscellaneous plastics products & 30 & 37 & 19 & 0.514 & 0.044 & 0.084 \\
\hline Leather and leather products & 31 & 16 & 13 & 0.813 & 0.151 & 0.186 \\
\hline Stone, clay, glass, and concrete products & 32 & 15 & 12 & 0.8 & 0.071 & 0.089 \\
\hline Primary metal industries & 33 & 59 & 41 & 0.695 & 0.089 & 0.128 \\
\hline Fabricated metal products & 34 & 53 & 34 & 0.642 & 0.077 & 0.12 \\
\hline Industrial machinery and equipment & 35 & 242 & 169 & 0.698 & 0.09 & 0.128 \\
\hline Electrical and electronic equipment & 36 & 359 & 250 & 0.696 & 0.111 & 0.159 \\
\hline Transportation equipment & 37 & 90 & 49 & 0.544 & 0.074 & 0.134 \\
\hline Instruments and related products & 38 & 274 & 177 & 0.646 & 0.099 & 0.153 \\
\hline Miscellaneous manufacturing industries & 39 & 32 & 17 & 0.531 & 0.051 & 0.095 \\
\hline Total & & 1807 & 1210 & 0.67 & 0.097 & 0.144 \\
\hline
\end{tabular}


Table II: New Security Issuance

The table presents security issuance decisions by public firms in private and public markets over our sample period. It presents the number of issues, the total gross proceeds raised in millions of dollars, the mean value of the proceeds of each issue as a fraction of the market value of the issuer's asset, and the mean value of the maturity for debt security issues. The sample consists of all security issues by 1,806 manufacturing firms during the fiscal year period of 2004-2011. Panel B shows the number of security issues by year and security type.

\begin{tabular}{lcccc}
\hline \hline PANEL A & & & & \\
Detailed Issue Type & \# issues & proceeds(\$million) & proceeds/market assets & maturity of debt \\
\hline Public Debt & 469 & 1212.17 & 0.05 & 10.79 \\
Public Conv. Debt & 80 & 365.79 & 0.12 & 7.19 \\
Public Conv. Preferred & 15 & 541.01 & 0.13 & \\
Public Equity & 639 & 185.02 & 0.16 & 8.06 \\
144A Debt & 90 & 361.47 & 0.15 & 8.95 \\
144A Conv. Debt & 176 & 413.55 & 0.14 & 4.44 \\
144A Conv. Preferred & 5 & 72.22 & 0.09 & \\
144A Equity & 5 & 17.76 & 0.19 & \\
Private Debt & 1,930 & 701.36 & 0.14 & 6.02 \\
Private Conv. Debt & 66 & 48.72 & 0.11 & \\
Private Conv. Preferred & 49 & 196 & 0.16 & \\
Private Equity & 205 & 35.75 & & \\
\hline Total & 3,729 & 590.95 & & \\
\hline \hline
\end{tabular}

\begin{tabular}{|c|c|c|c|c|c|c|c|c|c|}
\hline \multirow{2}{*}{$\begin{array}{l}\text { PANEL B } \\
\text { Detailed Issue Type }\end{array}$} & \multicolumn{8}{|c|}{ Data Year - Fiscal } & \multirow[b]{2}{*}{ Total } \\
\hline & 2004 & 2005 & 2006 & 2007 & 2008 & 2009 & 2010 & 2011 & \\
\hline Public Debt & 31 & 29 & 47 & 55 & 57 & 93 & 83 & 74 & 469 \\
\hline Public Conv. Debt & 2 & 4 & 12 & 14 & 11 & 20 & 9 & 8 & 80 \\
\hline Public Conv. Preferred & & 2 & & 1 & & 2 & 4 & 6 & 15 \\
\hline Public Equity & 104 & 69 & 83 & 76 & 26 & 129 & 96 & 56 & 639 \\
\hline 144A Debt & 25 & 28 & 6 & 19 & 4 & 8 & & & 90 \\
\hline 144A Conv. Debt & 47 & 26 & 35 & 27 & 7 & 10 & 9 & 15 & 176 \\
\hline 144A Conv. Preferred & 2 & & & & & 1 & 2 & & 5 \\
\hline 144A Equity & & & & & & 1 & 4 & & 5 \\
\hline Private Debt & 12 & 377 & 356 & 315 & 193 & 145 & 204 & 328 & 1,930 \\
\hline Private Conv. Debt & & 13 & 11 & 9 & 12 & 9 & 10 & 2 & 66 \\
\hline Private Conv. Preferred & & 11 & 4 & 7 & 8 & 9 & 5 & 5 & 49 \\
\hline Private Equity & 3 & 34 & 39 & 39 & 25 & 25 & 28 & 12 & 205 \\
\hline Total & 226 & 593 & 593 & 562 & 343 & 452 & 454 & 506 & 3,729 \\
\hline
\end{tabular}


Table III: New Security Issuance and Outsourcing Intensity by Firm Size

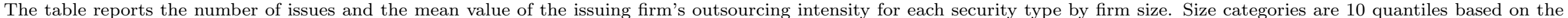

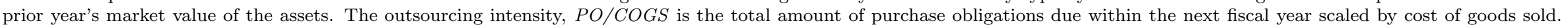
We combine Rule 144A securities with other public securities in the table.

\begin{tabular}{|c|c|c|c|c|c|c|c|c|c|c|c|}
\hline \multirow[b]{2}{*}{ Security Type } & & \multicolumn{10}{|c|}{10 Quantiles of the prior year's Market Value of Assets } \\
\hline & & 1 & 2 & 3 & 4 & 5 & 6 & 7 & 8 & 9 & 10 \\
\hline \multirow{2}{*}{ Public Debt } & \# Issues & & 1 & 1 & 1 & 7 & 6 & 23 & 46 & 133 & 279 \\
\hline & $\mathrm{PO} / \mathrm{COGS}$ & & 0 & 0 & 0 & 0.03 & 0.081 & 0.085 & 0.049 & 0.099 & 0.149 \\
\hline \multirow[t]{2}{*}{ Private Debt } & \# Issues & 35 & 64 & 84 & 135 & 166 & 202 & 257 & 294 & 324 & 356 \\
\hline & $\mathrm{PO} / \mathrm{COGS}$ & 0.045 & 0.11 & 0.102 & 0.084 & 0.06 & 0.075 & 0.108 & 0.083 & 0.1 & 0.156 \\
\hline \multirow[t]{2}{*}{ Public Convertible } & \# Issues & 2 & & 6 & 11 & 21 & 43 & 35 & 40 & 35 & 27 \\
\hline & $\mathrm{PO} / \mathrm{COGS}$ & 0.032 & & 0.155 & 0.019 & 0.175 & 0.17 & 0.22 & 0.138 & 0.097 & 0.264 \\
\hline \multirow[t]{2}{*}{ Private Convertible } & \# Issues & 37 & 14 & 18 & 11 & 10 & 5 & 6 & 3 & 4 & 4 \\
\hline & $\mathrm{PO} / \mathrm{COGS}$ & 0.016 & 0.111 & 0.113 & 0.09 & 0.054 & 0.042 & 0.213 & 0.344 & 0.035 & 0.144 \\
\hline \multirow[t]{2}{*}{ Public Equity } & \# Issues & 25 & 36 & 73 & 75 & 76 & 66 & 52 & 46 & 46 & 19 \\
\hline & $\mathrm{PO} / \mathrm{COGS}$ & 0.103 & 0.084 & 0.107 & 0.138 & 0.115 & 0.154 & 0.096 & 0.12 & 0.065 & 0.103 \\
\hline \multirow[t]{2}{*}{ Private Equity } & \# Issues & 42 & 42 & 39 & 33 & 19 & 8 & 7 & 8 & 1 & 3 \\
\hline & $\mathrm{PO} / \mathrm{COGS}$ & 0.089 & 0.101 & 0.165 & 0.108 & 0.177 & 0.095 & 0.25 & 0.117 & 0 & 0.132 \\
\hline
\end{tabular}


Table IV: Summary Statistics for Outsourcing vs. Non-outsourcing Firms

The table presents summary statistics for firms with purchase obligations versus firms without purchase obligations. All variable definitions are in Appendix C. The sample consists of 1,807 manufacturing firms during the fiscal year 2004-2010. ${ }^{* * *},{ }^{* *}$, and ${ }^{*}$ indicate statistical significance at the $1 \%, 5 \%$, and $10 \%$ level, respectively.

\begin{tabular}{|c|c|c|c|c|c|}
\hline & \multicolumn{2}{|c|}{ Outsourcing Firms } & \multicolumn{2}{|c|}{ Non-outsourcing Firms } & \multirow[b]{2}{*}{ Mean Difference } \\
\hline & Mean & Median & Mean & Median & \\
\hline $\mathrm{PO} / \mathrm{COGS}$ & 0.144 & 0.098 & 0.000 & 0.000 & $0.144^{* * *}$ \\
\hline $\log (\mathrm{mv}$ assets $)$ & 6.890 & 6.732 & 5.593 & 5.410 & $1.297^{* * *}$ \\
\hline NYSE size pct & 0.345 & 0.246 & 0.181 & 0.083 & $0.164^{* * *}$ \\
\hline $\log (1+$ age $)$ & 2.540 & 2.629 & 2.445 & 2.629 & $0.095^{* *}$ \\
\hline $\mathrm{M} / \mathrm{B}$ & 2.088 & 1.734 & 1.941 & 1.495 & $0.147^{* *}$ \\
\hline sales growth & 0.160 & 0.098 & 0.148 & 0.096 & 0.012 \\
\hline operating margin & -0.163 & 0.104 & -0.248 & 0.079 & 0.085 \\
\hline $\mathrm{ROA}$ & -0.000 & 0.037 & -0.021 & 0.021 & $0.021 * *$ \\
\hline cash/assets & 0.244 & 0.182 & 0.219 & 0.139 & $0.025^{* *}$ \\
\hline market leverage & 0.123 & 0.087 & 0.140 & 0.096 & $-0.016^{* *}$ \\
\hline book leverage & 0.187 & 0.151 & 0.194 & 0.141 & -0.007 \\
\hline value-added per emp & 0.060 & 0.033 & 0.037 & 0.020 & $0.022^{* * *}$ \\
\hline abnormal stock return & -0.004 & 0.011 & -0.048 & -0.013 & $0.043^{* * *}$ \\
\hline stock return volatility & 0.413 & 0.417 & 0.461 & 0.463 & $-0.048 * * *$ \\
\hline cash flow volatility (opmarg) & 0.278 & 0.038 & 0.429 & 0.038 & $-0.150^{* *}$ \\
\hline cash flow volatility (ROA) & 0.091 & 0.066 & 0.104 & 0.071 & $-0.013^{* * *}$ \\
\hline default probability & 0.021 & 0.000 & 0.051 & 0.000 & $-0.030 * * *$ \\
\hline marginal tax rate & 0.140 & 0.085 & 0.148 & 0.108 & -0.008 \\
\hline$\%$ foreign tax & 0.314 & 0.153 & 0.216 & 0.012 & $0.098 * * *$ \\
\hline compete (TNIC) & 0.763 & 0.848 & 0.684 & 0.754 & $0.079^{* * *}$ \\
\hline high-tech industry & 0.302 & 0.000 & 0.261 & 0.000 & $0.041^{*}$ \\
\hline $\mathrm{N}$ & \multicolumn{2}{|c|}{1210} & \multicolumn{2}{|c|}{597} & \\
\hline
\end{tabular}


Table V: Outsourcing and Cash Flow Volatility: Propensity Score Based Differences

The table presents the differences in firm cash flow volatility between outsourcing and matched non-outsourcing firms. We estimate a matching model using $\log (m v$ assets), $M / B$, market leverage, mean quarterly sales, compete (TNIC), and high-tech industry as matching variables. For each quarter, an outsourcing firm is the firm in the sample that has disclosed a non-zero amount of purchase obligations for the given fiscal year. The control observations for an outsourcing firm are the 10 nearest neighbors across the matching variables within the same FIC-25 code group by Hoberg and Phillips (2010a). The variable of interest is Standard Deviation of (ROS), which is the standard deviation of operating income before depreciation scaled by sales from the 12 previous quarters. Other variable definitions are available in the Appendix. Results are robust to using different matching variables or different numbers of control observations. ${ }^{* * *},{ }^{* *}$, and ${ }^{*}$ indicate statistical significance at $1 \%, 5 \%$, and $10 \%$ level, respectively.

\begin{tabular}{|c|c|c|c|c|c|}
\hline Quarter & [Outsourcing - Non outsourcing] & Std. Err. & $\mathrm{z}$ & $\mathrm{P}>\mathrm{Z}$ & $\mathrm{N}$ \\
\hline \multicolumn{6}{|c|}{ Standard Deviation of ROS (Operating Margin) } \\
\hline all quarters & $-0.022 *$ & 0.012 & -1.793 & 0.073 & 1685 \\
\hline $2004 q 1$ & -0.025 & 0.016 & -1.511 & 0.131 & 1243 \\
\hline $2004 q 2$ & $-0.027 *$ & 0.016 & -1.65 & 0.099 & 1258 \\
\hline $2004 q 3$ & $-0.029 *$ & 0.016 & -1.852 & 0.064 & 1258 \\
\hline $2004 q 4$ & $-0.031 * *$ & 0.015 & -2.092 & 0.036 & 1259 \\
\hline $2005 q 1$ & $-0.025 *$ & 0.014 & -1.757 & 0.079 & 1416 \\
\hline $2005 q 2$ & $-0.024 *$ & 0.014 & -1.659 & 0.097 & 1427 \\
\hline $2005 q 3$ & -0.019 & 0.014 & -1.402 & 0.161 & 1428 \\
\hline $2005 q 4$ & -0.021 & 0.013 & -1.559 & 0.119 & 1426 \\
\hline $2006 q 1$ & $-0.032 * *$ & 0.015 & -2.219 & 0.026 & 1381 \\
\hline $2006 \mathrm{q} 2$ & $-0.030 * *$ & 0.015 & -2.056 & 0.04 & 1391 \\
\hline $2006 q 3$ & $-0.027 *$ & 0.015 & -1.821 & 0.069 & 1388 \\
\hline $2006 q 4$ & -0.02 & 0.014 & -1.427 & 0.154 & 1388 \\
\hline $2007 q 1$ & $-0.024 *$ & 0.015 & -1.683 & 0.092 & 1338 \\
\hline $2007 \mathrm{q} 2$ & $-0.026 *$ & 0.015 & -1.782 & 0.075 & 1346 \\
\hline $2007 \mathrm{q} 3$ & $-0.025 *$ & 0.015 & -1.728 & 0.084 & 1349 \\
\hline $2007 q 4$ & $-0.027 *$ & 0.015 & -1.82 & 0.069 & 1351 \\
\hline 2008q1 & -0.021 & 0.016 & -1.28 & 0.201 & 1288 \\
\hline $2008 \mathrm{q} 2$ & -0.019 & 0.016 & -1.206 & 0.228 & 1295 \\
\hline $2008 \mathrm{q} 3$ & -0.023 & 0.016 & -1.397 & 0.162 & 1297 \\
\hline $2008 q 4$ & -0.024 & 0.016 & -1.477 & 0.14 & 1293 \\
\hline $2009 \mathrm{q} 1$ & $-0.051 * * *$ & 0.018 & -2.796 & 0.005 & 1067 \\
\hline $2009 \mathrm{q} 2$ & $-0.052 * * *$ & 0.018 & -2.899 & 0.004 & 1069 \\
\hline $2009 \mathrm{q} 3$ & $-0.048 * * *$ & 0.018 & -2.752 & 0.006 & 1069 \\
\hline $2009 q 4$ & $-0.046 * * *$ & 0.016 & -2.778 & 0.005 & 1069 \\
\hline $2010 \mathrm{q} 1$ & $-0.034 * *$ & 0.016 & -2.131 & 0.033 & 1010 \\
\hline $2010 \mathrm{q} 2$ & $-0.037 * *$ & 0.016 & -2.321 & 0.02 & 1011 \\
\hline $2010 q 3$ & $-0.037 * *$ & 0.016 & -2.295 & 0.022 & 1011 \\
\hline $2010 q 4$ & $-0.041 * *$ & 0.016 & -2.527 & 0.012 & 1011 \\
\hline
\end{tabular}


Table VI: Cost Fluctuations in Outsourcing versus Non-outsourcing Firms

The table shows the cost fluctuations based on downstream demand shocks for outsourcing versus non-outsourcing firms. Each column presents coefficient estimates from an OLS regression with firm-fixed effects. COGS and $S G \mathcal{E} A$ represent Cost of Goods Sold and Selling, General \& Administrative Expense, respectively. The dependent variables are scaled by the average sales of the firm during the sample period. demand shock is the detrended annual percentage change in the downstream industry demands using the chain-type quantity indexes for gross output by industry and the 2002 input-output benchmark table from the Bureau of Economic Analysis, following Maksimovic and Phillips (2001). To detrend this variable, we regress it on industry and year fixed effects indicators and then take the residual from the regression. negative demand shock is a discretized version of demand shock, which equals one when demand shock is negative and zero otherwise. The Panel A sample includes firms that disclose a non-zero amount of purchase obligations at least once during the sample period, and otherwise firms are included in the Panel B sample. All specifications have firm fixed effects. t-statistics (in parenthesis) are robust and adjusted for clustering at the firm level. ***, ${ }^{* *}$, and ${ }^{*}$ indicate statistical significance at $1 \%, 5 \%$, and $10 \%$ level, respectively.

\begin{tabular}{lccc}
\hline \hline PANEL A: Outsourcing Firms & (COGS+SG\&A)/avrg sales & COGS/avrg sales & SG\&A/avrg sales \\
\hline negative demand shock & $-0.0447^{* * *}$ & $-0.0268^{* * *}$ & $-0.0161^{* * *}$ \\
& $(-6.00)$ & $(-4.18)$ & $(-4.00)$ \\
\hline Observations & 6826 & 6826 & 6826 \\
Adjusted $R^{2}$ & 0.598 & 0.671 & 0.739 \\
\hline
\end{tabular}

\begin{tabular}{lccc}
\hline PANEL B: Non-Outsourcing Firms & (COGS+SG\&A)/avrg sales & COGS/avrg sales & SG\&A/avrg sales \\
\hline negative demand shock & $-0.0224^{*}$ & -0.0152 & -0.00410 \\
& $(-1.82)$ & $(-1.57)$ & $(-0.65)$ \\
\hline Observations & 2998 & 2998 & 2998 \\
Adjusted $R^{2}$ & 0.574 & 0.676 & 0.764 \\
\hline \hline
\end{tabular}




\section{Table VII: Outsourcing Propensity}

The table presents outsourcing propensity estimates from Tobit and Linear Probability regressions. The dependent variable, $P O / C O G S$ is the total amount of purchase obligations due within the next fiscal year scaled by cost of goods sold. The first two results are from the firm-level between estimations, and others are from the firm-year level panel estimations. We estimate both tobit and linear probability models for panel regressions. We use two instrumental variables, close to port and high transp cost. close to port equals 1 if the minimum distance to any entry ports including seaports, airports, and border crossings is in the lowest tercile of the sample. high transp cost equals 1 if the average (purchase value weighted) industry transportation cost of inputs from other industries is in the highest tercile. Detailed variable definitions are available in the Appendix. t-statistics (in parenthesis) are robust and adjusted for industry-year clustering. ${ }^{* * *},{ }^{* *}$, and ${ }^{*}$ indicate statistical significance at $1 \%, 5 \%$, and $10 \%$ level, respectively.

\begin{tabular}{|c|c|c|c|c|c|c|}
\hline \multirow{3}{*}{$\begin{array}{l}\text { Estimation Method } \\
\text { close to port }\end{array}$} & \multirow{2}{*}{\multicolumn{2}{|c|}{ Firm Level Between Regression }} & \multirow{2}{*}{\multicolumn{2}{|c|}{$\begin{array}{c}\text { Firm-Year Level Tobit } \\
\text { PO/COGS }\end{array}$}} & \multicolumn{2}{|c|}{ Firm-Year Level OLS } \\
\hline & & & & & & \\
\hline & $\begin{array}{c}0.0139^{* *} \\
(2.17)\end{array}$ & $\begin{array}{c}0.0142^{* *} \\
(2.20)\end{array}$ & $\begin{array}{c}0.0145^{* * *} \\
(2.69)\end{array}$ & $\begin{array}{c}0.0209^{* * *} \\
(3.64)\end{array}$ & $\begin{array}{c}0.00591 \\
(1.61)\end{array}$ & $\begin{array}{c}0.00941^{* *} \\
(2.40)\end{array}$ \\
\hline high transp cost & $\begin{array}{c}-0.0234^{*} \\
(-1.90)\end{array}$ & $\begin{array}{c}-0.0114 \\
(-1.08)\end{array}$ & $\begin{array}{c}-0.0233^{* * *} \\
(-3.15)\end{array}$ & $\begin{array}{c}-0.0160^{* *} \\
(-2.14)\end{array}$ & $\begin{array}{c}-0.0264^{* * *} \\
(-5.29)\end{array}$ & $\begin{array}{c}-0.0220^{* * *} \\
(-4.28)\end{array}$ \\
\hline $\log (\mathrm{mv}$ assets $)$ & $\begin{array}{c}0.0256^{* * *} \\
(7.24)\end{array}$ & $\begin{array}{c}0.0213^{* * *} \\
(6.64)\end{array}$ & $\begin{array}{c}0.0359^{* * *} \\
(16.38)\end{array}$ & $\begin{array}{c}0.0333^{* * *} \\
(15.96)\end{array}$ & $\begin{array}{c}0.0158^{* * *} \\
(11.82)\end{array}$ & $\begin{array}{c}0.0136^{* * *} \\
(10.64)\end{array}$ \\
\hline $\log (1+$ age $)$ & $\begin{array}{c}-0.00371 \\
(-0.75)\end{array}$ & $\begin{array}{c}-0.00533 \\
(-1.51)\end{array}$ & $\begin{array}{c}-0.00317 \\
(-0.69)\end{array}$ & $\begin{array}{c}-0.00254 \\
(-0.54)\end{array}$ & $\begin{array}{c}0.00205 \\
(0.67)\end{array}$ & $\begin{array}{c}0.00180 \\
(0.57)\end{array}$ \\
\hline operating margin & $\begin{array}{c}0.00551^{* * *} \\
(2.83)\end{array}$ & $\begin{array}{c}0.00508^{* * *} \\
\quad(3.06)\end{array}$ & $\begin{array}{c}-0.000136 \\
(-0.06)\end{array}$ & $\begin{array}{c}0.000309 \\
(0.13)\end{array}$ & $\begin{array}{c}0.000185 \\
(0.12)\end{array}$ & $\begin{array}{c}0.000250 \\
(0.17)\end{array}$ \\
\hline cash flow volatility & $\begin{array}{c}-0.00187 \\
(-0.08)\end{array}$ & $\begin{array}{c}0.00837 \\
(0.32)\end{array}$ & $\begin{array}{c}0.00485 \\
(0.30)\end{array}$ & $\begin{array}{c}0.00628 \\
(0.37)\end{array}$ & $\begin{array}{c}0.00823 \\
(0.80)\end{array}$ & $\begin{array}{c}0.0112 \\
(1.00)\end{array}$ \\
\hline $\mathrm{M} / \mathrm{B}$ & $\begin{array}{c}0.00594 \\
(1.18)\end{array}$ & $\begin{array}{c}0.00702 \\
(1.40)\end{array}$ & $\begin{array}{c}0.00415 \\
(1.23)\end{array}$ & $\begin{array}{c}0.00361 \\
(0.99)\end{array}$ & $\begin{array}{c}0.00594^{* * *} \\
(2.68)\end{array}$ & $\begin{array}{c}0.00664^{* * *} \\
(2.88)\end{array}$ \\
\hline sales growth & $\begin{array}{c}0.0698^{* *} \\
(2.40)\end{array}$ & $\begin{array}{c}0.0684^{* *} \\
(2.29)\end{array}$ & $\begin{array}{c}0.0307^{* *} \\
(2.17)\end{array}$ & $\begin{array}{c}0.0256^{*} \\
(1.82)\end{array}$ & $\begin{array}{c}0.0228^{* *} \\
(2.17)\end{array}$ & $\begin{array}{c}0.0204^{* *} \\
(1.98)\end{array}$ \\
\hline abnormal stock return & $\begin{array}{c}0.0930^{* *} \\
(2.42)\end{array}$ & $\begin{array}{c}0.0923^{* *} \\
(2.52)\end{array}$ & $\begin{array}{c}0.0290^{*} \\
(1.67)\end{array}$ & $\begin{array}{c}0.0390^{* *} \\
(2.13)\end{array}$ & $\begin{array}{c}0.0162 \\
(1.61)\end{array}$ & $\begin{array}{c}0.0201^{*} \\
(1.89)\end{array}$ \\
\hline stock return volatility & $\begin{array}{c}0.0221 \\
(0.21)\end{array}$ & $\begin{array}{c}-0.0375 \\
(-0.38)\end{array}$ & $\begin{array}{c}0.0722^{*} \\
(1.89)\end{array}$ & $\begin{array}{c}0.0581^{* *} \\
(1.97)\end{array}$ & $\begin{array}{c}0.0422^{*} \\
(1.78)\end{array}$ & $\begin{array}{c}0.0241 \\
(1.32)\end{array}$ \\
\hline$\%$ foreign tax & $\begin{array}{c}-0.0000171 \\
(-0.00)\end{array}$ & $\begin{array}{c}-0.000312 \\
(-0.03)\end{array}$ & $\begin{array}{c}-0.00721^{*} \\
(-1.65)\end{array}$ & $\begin{array}{c}-0.00340 \\
(-0.69)\end{array}$ & $\begin{array}{c}-0.00821^{* * *} \\
(-2.72)\end{array}$ & $\begin{array}{c}-0.00704^{* *} \\
(-2.12)\end{array}$ \\
\hline high ind PO/COGS & $\begin{array}{c}0.0497^{* *} \\
(1.97)\end{array}$ & $\begin{array}{c}0.0416^{* * *} \\
(4.57)\end{array}$ & $\begin{array}{c}0.0250^{* * *} \\
\quad(3.30)\end{array}$ & $\begin{array}{c}0.0585^{* * *} \\
\quad(7.27)\end{array}$ & $\begin{array}{c}0.0182^{* * *} \\
(3.69)\end{array}$ & $\begin{array}{c}0.0390^{* * *} \\
(8.02)\end{array}$ \\
\hline compete(TNIC) & & $\begin{array}{c}0.0658^{* * *} \\
(3.40)\end{array}$ & & $\begin{array}{c}0.0607^{* * *} \\
(3.80)\end{array}$ & & $\begin{array}{c}0.0373^{* * *} \\
(4.44)\end{array}$ \\
\hline high-tech Ind & & $\begin{array}{c}0.0200 \\
(1.34)\end{array}$ & & $\begin{array}{c}0.0195^{* *} \\
(2.55)\end{array}$ & & $\begin{array}{c}0.00698 \\
(1.39)\end{array}$ \\
\hline Aaa bond rate & & & & $\begin{array}{c}-0.00213 \\
(-0.31)\end{array}$ & & $\begin{array}{c}-0.00403 \\
(-0.99)\end{array}$ \\
\hline credit spread: Baa-Aaa & & & & $\begin{array}{c}0.00383 \\
(0.71)\end{array}$ & & $\begin{array}{c}0.00295 \\
(0.77)\end{array}$ \\
\hline Observations & 1455 & 1461 & 7686 & 7377 & 7686 & 7356 \\
\hline Pseudo $R^{2}$ & 0.804 & 0.730 & 0.219 & 0.183 & 0.084 & 0.077 \\
\hline $\mathrm{F}$ & 164.51 & 148.0 & 40.22 & 50.30 & 74.12 & 49.66 \\
\hline Fixed Effects & Ind & None & Ind, Year & None & Ind, Year & None \\
\hline
\end{tabular}


Table VIII: Outsourcing and Leverage: Propensity Score Based Differences

The table presents the differences in leverage between outsourcing and matched non-outsourcing firms. We estimate a matching model using $\log (m v$ assets), $\log$ (quarterly sales), $M / B$, operating margin, cash flow volatility, PPE/assets, \#patents/assets, and high-tech industry as matching variables. For each quarter, an outsourcing firm is the firm in the sample that has disclosed a non-zero amount of purchase obligations for the given fiscal year. The control observations for an outsourcing firm are the 10 nearest neighbors across the matching variables within the same FIC-25 code group by Hoberg and Phillips (2010a). The variable of interest is market leverage, which is the ratio of total debt to the market value of assets. Market value of total assets is market value of common equity plus book value of preferred stock plus debt (long-term debt + debt in current liabilities) plus book value of minority interest. Other variable definitions are available in the Appendix. Results are robust to using different matching variables and different numbers of control observations. ${ }^{* * *},{ }^{* *}$, and ${ }^{*}$ indicate statistical significance at $1 \%, 5 \%$, and $10 \%$ level, respectively.

\begin{tabular}{|c|c|c|c|c|c|}
\hline Quarter & [Outsourcing - Non outsourcing] & Std. Err. & $\mathrm{z}$ & $\mathrm{P}>\mathrm{Z}$ & $\mathrm{N}$ \\
\hline \multicolumn{6}{|c|}{ Market Leverage } \\
\hline all quarters & $-0.019 * *$ & 0.009 & -2.119 & 0.034 & 1694 \\
\hline $2004 q 1$ & 0.006 & 0.01 & 0.597 & 0.55 & 1160 \\
\hline $2004 q 2$ & 0.012 & 0.01 & 1.215 & 0.224 & 1168 \\
\hline $2004 \mathrm{q} 3$ & 0.009 & 0.01 & 0.899 & 0.369 & 1167 \\
\hline $2004 q 4$ & 0.004 & 0.009 & 0.394 & 0.694 & 1175 \\
\hline $2005 q 1$ & 0.006 & 0.009 & 0.645 & 0.519 & 1315 \\
\hline $2005 q 2$ & 0.005 & 0.009 & 0.597 & 0.55 & 1338 \\
\hline $2005 q 3$ & 0.004 & 0.009 & 0.457 & 0.648 & 1335 \\
\hline $2005 \mathrm{q} 4$ & -0.001 & 0.009 & -0.095 & 0.924 & 1344 \\
\hline $2006 \mathrm{q} 1$ & -0.001 & 0.009 & -0.081 & 0.936 & 1297 \\
\hline $2006 \mathrm{q} 2$ & 0.002 & 0.009 & 0.21 & 0.833 & 1310 \\
\hline $2006 \mathrm{q} 3$ & 0.000 & 0.009 & 0.033 & 0.973 & 1298 \\
\hline $2006 \mathrm{q} 4$ & -0.005 & 0.009 & -0.575 & 0.566 & 1305 \\
\hline $2007 q 1$ & -0.015 & 0.009 & -1.615 & 0.106 & 1261 \\
\hline $2007 \mathrm{q} 2$ & $-0.017 *$ & 0.009 & -1.8 & 0.072 & 1270 \\
\hline $2007 q 3$ & $-0.023 * *$ & 0.01 & -2.242 & 0.025 & 1272 \\
\hline $2007 q 4$ & -0.017 & 0.011 & -1.566 & 0.117 & 1278 \\
\hline $2008 q 1$ & $-0.028 * *$ & 0.011 & -2.411 & 0.016 & 1223 \\
\hline $2008 \mathrm{q} 2$ & $-0.027 * *$ & 0.012 & -2.236 & 0.025 & 1238 \\
\hline $2008 \mathrm{q} 3$ & $-0.037 * * *$ & 0.013 & -2.874 & 0.004 & 1238 \\
\hline $2008 \mathrm{q} 4$ & $-0.057 * * *$ & 0.015 & -3.717 & 0 & 1244 \\
\hline $2009 q 1$ & $-0.035 * *$ & 0.016 & -2.255 & 0.024 & 1181 \\
\hline $2009 q 2$ & $-0.031 * *$ & 0.014 & -2.216 & 0.027 & 1190 \\
\hline $2009 q 3$ & $-0.033 * * *$ & 0.012 & -2.649 & 0.008 & 1187 \\
\hline $2009 q 4$ & $-0.036 * * *$ & 0.012 & -2.907 & 0.004 & 1192 \\
\hline 2010q1 & $-0.027 * *$ & 0.012 & -2.34 & 0.019 & 1124 \\
\hline $2010 q 2$ & $-0.022 *$ & 0.012 & -1.84 & 0.066 & 1120 \\
\hline $2010 \mathrm{q} 3$ & $-0.023 *$ & 0.012 & -1.936 & 0.053 & 1114 \\
\hline $2010 q 4$ & $-0.018 *$ & 0.011 & -1.68 & 0.093 & 1124 \\
\hline
\end{tabular}


Table IX: Outsourcing and Leverage

The table analyzes the impact of outsourcing intensity on leverage. It reports estimates from leverage regressions using an instrumental variable approach with close to port and high transp cost as instrumental variables for PO/COGS. The dependent variable, market leverage (book leverage) is the ratio of total debt to the market (book) value of assets. Market value of total assets is market value of common equity plus book value of preferred stock plus debt (long-term debt + debt in current liabilities) plus book value of minority interest. In column two and three, market leverage is computed by additionally including account payables as part of total debt. Other variable definitions are available in the Appendix. The sample consists of all firm-years in the manufacturing sector during the period of 2005-2011. All the control variables from the outsourcing intensity prediction regression (column five and six in Table VII) are included. Industry fixed effects are at the FIC-25 code group level following Hoberg and Phillips (2010a). t-statistics (in parenthesis) are robust and adjusted for industry-year clustering. ${ }^{* * *},{ }^{* *}$, and ${ }^{*}$ indicate statistical significance at $1 \%, 5 \%$, and $10 \%$ level, respectively.

\begin{tabular}{|c|c|c|c|c|c|c|}
\hline \multirow{3}{*}{$\begin{array}{l}\text { Estimation Method } \\
\text { PO/COGS (instr.) }\end{array}$} & \multicolumn{6}{|c|}{ Instrumental Variable Approach } \\
\hline & \multicolumn{2}{|c|}{ market leverage } & \multicolumn{2}{|c|}{ market leverage (with $A P$ ) } & \multicolumn{2}{|c|}{ book leverage } \\
\hline & $\begin{array}{c}-0.790^{* * *} \\
(-4.83)\end{array}$ & $\begin{array}{c}-1.227^{* * *} \\
(-6.46)\end{array}$ & $\begin{array}{c}-0.752^{* * *} \\
(-4.46)\end{array}$ & $\begin{array}{c}-1.151^{* * *} \\
(-5.16)\end{array}$ & $\begin{array}{c}-1.011^{* * *} \\
(-4.34)\end{array}$ & $\begin{array}{c}-1.731^{* * *} \\
(-6.84)\end{array}$ \\
\hline $\log (\mathrm{mv}$ assets) (lagged) & $\begin{array}{c}0.0343^{* * *} \\
(11.92)\end{array}$ & $\begin{array}{c}0.0358^{* * *} \\
(12.59)\end{array}$ & $\begin{array}{c}0.0311^{* * *} \\
(10.19)\end{array}$ & $\begin{array}{c}0.0309^{* * *} \\
(9.46)\end{array}$ & $\begin{array}{c}0.0521^{* * *} \\
(13.17)\end{array}$ & $\begin{array}{c}0.0565^{* * *} \\
(14.62)\end{array}$ \\
\hline $\log (1+$ age $)$ & $\begin{array}{c}-0.0106^{* *} \\
(-2.19)\end{array}$ & $\begin{array}{c}-0.00984^{* *} \\
(-2.09)\end{array}$ & $\begin{array}{c}-0.00824^{*} \\
(-1.74)\end{array}$ & $\begin{array}{c}-0.00872^{*} \\
(-1.79)\end{array}$ & $\begin{array}{c}-0.00964^{*} \\
(-1.66)\end{array}$ & $\begin{array}{c}-0.00892 \\
(-1.64)\end{array}$ \\
\hline PPE/assets (lagged) & $\begin{array}{c}0.00944 \\
(0.91)\end{array}$ & $\begin{array}{c}0.00279 \\
(0.27)\end{array}$ & $\begin{array}{c}0.0256^{* *} \\
(2.29)\end{array}$ & $\begin{array}{c}0.0233^{* *} \\
(1.98)\end{array}$ & $\begin{array}{c}0.00670 \\
(0.48)\end{array}$ & $\begin{array}{c}-0.0130 \\
(-0.96)\end{array}$ \\
\hline operating margin (lagged) & $\begin{array}{c}-0.00125^{*} \\
(-1.97)\end{array}$ & $\begin{array}{c}-0.00164^{* * *} \\
(-2.71)\end{array}$ & $\begin{array}{c}-0.00114^{*} \\
(-1.85)\end{array}$ & $\begin{array}{c}-0.00151^{* *} \\
(-2.39)\end{array}$ & $\begin{array}{c}-0.00467^{* * *} \\
(-3.28)\end{array}$ & $\begin{array}{c}-0.00527^{* * *} \\
(-3.57)\end{array}$ \\
\hline cash flow volatility (lagged) & $\begin{array}{c}0.000335 \\
(0.05)\end{array}$ & $\begin{array}{l}0.0113 \\
(1.44)\end{array}$ & $\begin{array}{c}-0.0113 \\
(-1.30)\end{array}$ & $\begin{array}{c}-0.00461 \\
(-0.50)\end{array}$ & $\begin{array}{c}0.0378^{* *} \\
(2.30)\end{array}$ & $\begin{array}{c}0.0561^{* * *} \\
(3.23)\end{array}$ \\
\hline M/B (lagged) & $\begin{array}{c}-0.0261^{* * *} \\
(-9.35)\end{array}$ & $\begin{array}{c}-0.0207^{* * *} \\
(-7.52)\end{array}$ & $\begin{array}{c}-0.0367^{* * *} \\
(-9.24)\end{array}$ & $\begin{array}{c}-0.0316^{* * *} \\
(-8.39)\end{array}$ & $\begin{array}{c}-0.0114^{* * *} \\
(-3.81)\end{array}$ & $\begin{array}{c}-0.00308 \\
(-1.12)\end{array}$ \\
\hline sales growth (lagged) & $\begin{array}{c}0.0228^{* * *} \\
(4.35)\end{array}$ & $\begin{array}{l}0.0328^{* * *} \\
(5.64)\end{array}$ & $\begin{array}{c}0.0255^{* * *} \\
(4.68)\end{array}$ & $\begin{array}{c}0.0364^{* * *} \\
\quad(5.68)\end{array}$ & $\begin{array}{c}0.0149^{* *} \\
(2.10)\end{array}$ & $\begin{array}{c}0.0308^{* * *} \\
(4.05)\end{array}$ \\
\hline abnormal stock return (lagged) & $\begin{array}{c}-0.0834^{* * *} \\
(-6.63)\end{array}$ & $\begin{array}{c}-0.0812^{* * *} \\
(-6.43)\end{array}$ & $\begin{array}{c}-0.108^{* * *} \\
(-7.63)\end{array}$ & $\begin{array}{c}-0.105^{* * *} \\
(-7.66)\end{array}$ & $\begin{array}{c}-0.0891^{* * *} \\
(-6.02)\end{array}$ & $\begin{array}{c}-0.0811^{* * *} \\
(-5.33)\end{array}$ \\
\hline stock return volatility (lagged) & $\begin{array}{c}0.308^{* * *} \\
(13.22)\end{array}$ & $\begin{array}{c}0.152^{* * *} \\
(6.84)\end{array}$ & $\begin{array}{c}0.388^{* * *} \\
(14.60)\end{array}$ & $\begin{array}{c}0.180^{* * *} \\
(6.00)\end{array}$ & $\begin{array}{c}0.362^{* * *} \\
(12.21)\end{array}$ & $\begin{array}{c}0.171^{* * *} \\
(6.73)\end{array}$ \\
\hline$\%$ foreign tax (lagged) & $\begin{array}{c}-0.00371 \\
(-1.35)\end{array}$ & $\begin{array}{c}-0.0110^{* * *} \\
(-3.68)\end{array}$ & $\begin{array}{c}0.000468 \\
(0.16)\end{array}$ & $\begin{array}{c}-0.00580^{*} \\
(-1.75)\end{array}$ & $\begin{array}{c}-0.00581 \\
(-1.55)\end{array}$ & $\begin{array}{c}-0.0153^{* * *} \\
(-3.74)\end{array}$ \\
\hline high ind PO/COGS (lagged) & $\begin{array}{c}0.0123^{* *} \\
(2.30)\end{array}$ & $\begin{array}{c}0.0368^{* * *} \\
(3.97)\end{array}$ & $\begin{array}{c}0.0111^{*} \\
(1.86)\end{array}$ & $\begin{array}{l}0.0192 \\
(1.62)\end{array}$ & $\begin{array}{c}0.00989 \\
(1.52)\end{array}$ & $\begin{array}{l}0.0597^{* * *} \\
(4.93)\end{array}$ \\
\hline compete(TNIC) (lagged) & & $\begin{array}{c}-0.00939 \\
(-0.93)\end{array}$ & & $\begin{array}{c}-0.0147 \\
(-1.11)\end{array}$ & & $\begin{array}{c}-0.00433 \\
(-0.34)\end{array}$ \\
\hline high-tech industry & & $\begin{array}{c}-0.0261^{* * *} \\
(-5.73)\end{array}$ & & $\begin{array}{c}-0.0218^{* * *} \\
(-3.95)\end{array}$ & & $\begin{array}{c}-0.0383^{* * *} \\
(-7.69)\end{array}$ \\
\hline Aaa bond rate & & $\begin{array}{c}0.00354 \\
(0.68)\end{array}$ & & $\begin{array}{c}0.00135 \\
(0.27)\end{array}$ & & $\begin{array}{c}0.0122^{*} \\
(1.75)\end{array}$ \\
\hline credit spread: Baa-Aaa & & $\begin{array}{c}0.0304^{* * *} \\
(7.38)\end{array}$ & & $\begin{array}{c}0.0425^{* * *} \\
(9.61)\end{array}$ & & $\begin{array}{c}0.00797 \\
(1.34)\end{array}$ \\
\hline Observations & 7801 & 7470 & 7801 & 7470 & 7801 & 7470 \\
\hline Adjusted $R^{2}$ & 0.258 & 0.215 & 0.303 & 0.263 & 0.196 & 0.148 \\
\hline Fixed Effects & Ind, Year & None & Ind, Year & None & Ind, Year & None \\
\hline
\end{tabular}


Table X: Outsourcing, Leverage and Measures of Human Capital

The table examines the impact of outsourcing and industry value added per employee on financial leverage. We use an instrumental variable approach with close to port and high transp cost as instrumental variables for PO/COGS. high ind VAE is an industry-level dummy variable that equals one if a given industry's value added per employee (VAE) is greater than the sample median. high $R \mathscr{E} D$ is an industry-level dummy variable that equals one if a given industry's $R \mathscr{E} D /$ sales is in the highest tercile. Other variable definitions are available in the Appendix. All the control variables from the outsourcing intensity prediction regression (column five in Table VII) are included. t-statistics (in parenthesis) are robust and adjusted for industry-year clustering. ${ }^{* * *},{ }^{* *}$, and ${ }^{*}$ indicate statistical significance at $1 \%, 5 \%$, and $10 \%$ level, respectively.

\begin{tabular}{|c|c|c|c|c|c|c|}
\hline \multirow{4}{*}{$\begin{array}{l}\text { Estimation Method } \\
\text { PO/COGS * high ind VAE (instr.) }\end{array}$} & \multicolumn{6}{|c|}{ Instrumental Variable Approach } \\
\hline & All & High R\&D & Low R\&D & All & High R\&D & Low $\mathrm{R} \& \mathrm{D}$ \\
\hline & \multicolumn{3}{|c|}{ book leverage } & \multicolumn{3}{|c|}{ market leverage } \\
\hline & $\begin{array}{c}-3.694^{* *} \\
(-2.39)\end{array}$ & $\begin{array}{c}-11.95^{* * *} \\
(-3.75)\end{array}$ & $\begin{array}{l}-0.170 \\
(-0.12)\end{array}$ & $\begin{array}{c}-2.120^{* *} \\
(-2.42)\end{array}$ & $\begin{array}{c}-5.537^{* * *} \\
(-3.86)\end{array}$ & $\begin{array}{l}-0.713 \\
(-0.72)\end{array}$ \\
\hline PO/COGS (instr.) & $\begin{array}{c}0.0886 \\
(0.15)\end{array}$ & $\begin{array}{c}3.993^{* * *} \\
(3.26)\end{array}$ & $\begin{array}{c}-1.239^{* *} \\
(-2.41)\end{array}$ & $\begin{array}{l}-0.159 \\
(-0.47)\end{array}$ & $\begin{array}{c}1.630^{* *} \\
(2.58)\end{array}$ & $\begin{array}{l}-0.608 \\
(-1.64)\end{array}$ \\
\hline high ind VAE & $\begin{array}{c}0.00130 \\
(0.28)\end{array}$ & $\begin{array}{c}-0.00277 \\
(-0.32)\end{array}$ & $\begin{array}{c}0.00282 \\
(0.57)\end{array}$ & $\begin{array}{c}-0.00307 \\
(-0.69)\end{array}$ & $\begin{array}{c}-0.00986^{*} \\
(-1.87)\end{array}$ & $\begin{array}{c}0.000155 \\
(0.03)\end{array}$ \\
\hline Log(mv assets) (lagged) & $\begin{array}{c}0.0580^{* * *} \\
(14.13)\end{array}$ & $\begin{array}{c}0.0511^{* * * *} \\
(4.39)\end{array}$ & $\begin{array}{c}0.0563^{* * *} \\
(12.48)\end{array}$ & $\begin{array}{c}0.0374^{* * *} \\
(12.94)\end{array}$ & $\begin{array}{c}0.0294^{* * *} \\
\quad(5.01)\end{array}$ & $\begin{array}{c}0.0368^{* * *} \\
(10.81)\end{array}$ \\
\hline $\log (1+$ age $)$ & $\begin{array}{c}-0.0140^{* *} \\
(-2.47)\end{array}$ & $\begin{array}{c}0.00300 \\
(0.68)\end{array}$ & $\begin{array}{c}-0.0225^{* * *} \\
(-3.32)\end{array}$ & $\begin{array}{c}-0.0137^{* * *} \\
(-2.90)\end{array}$ & $\begin{array}{c}-0.00188 \\
(-0.58)\end{array}$ & $\begin{array}{c}-0.0197^{* * *} \\
(-3.36)\end{array}$ \\
\hline PPE/assets (lagged) & $\begin{array}{c}-0.00150 \\
(-0.11)\end{array}$ & $\begin{array}{l}0.0168 \\
(0.45)\end{array}$ & $\begin{array}{c}-0.00516 \\
(-0.33)\end{array}$ & $\begin{array}{c}0.00539 \\
(0.54)\end{array}$ & $\begin{array}{c}0.0255 \\
(1.20)\end{array}$ & $\begin{array}{c}0.00392 \\
(0.33)\end{array}$ \\
\hline operating margin (lagged) & $\begin{array}{c}-0.00813^{* * *} \\
(-3.49)\end{array}$ & $\begin{array}{c}-0.0171^{* * *} \\
(-3.84)\end{array}$ & $\begin{array}{c}-0.00887 \\
(-1.64)\end{array}$ & $\begin{array}{c}-0.00322^{* *} \\
(-2.58)\end{array}$ & $\begin{array}{c}-0.00786^{* * *} \\
(-3.89)\end{array}$ & $\begin{array}{c}-0.0000502 \\
(-0.02)\end{array}$ \\
\hline cash flow volatility (lagged) & $\begin{array}{c}0.0282 \\
(1.63)\end{array}$ & $\begin{array}{l}0.0232 \\
(1.14)\end{array}$ & $\begin{array}{l}0.0428 \\
(1.34)\end{array}$ & $\begin{array}{c}-0.00739 \\
(-1.02)\end{array}$ & $\begin{array}{c}-0.00675 \\
(-0.91)\end{array}$ & $\begin{array}{c}0.00275 \\
(0.10)\end{array}$ \\
\hline M/B (lagged) & $\begin{array}{c}-0.0198^{* * *} \\
(-3.70)\end{array}$ & $\begin{array}{c}-0.0455^{* * *} \\
(-4.25)\end{array}$ & $\begin{array}{c}-0.0143^{* *} \\
(-2.24)\end{array}$ & $\begin{array}{c}-0.0308^{* * *} \\
(-10.06)\end{array}$ & $\begin{array}{c}-0.0326^{* * *} \\
(-6.25)\end{array}$ & $\begin{array}{c}-0.0410^{* * *} \\
(-9.21)\end{array}$ \\
\hline sales growth (lagged) & $\begin{array}{l}0.0329^{* * *} \\
\quad(3.27)\end{array}$ & $\begin{array}{c}0.0512^{* *} \\
(2.71)\end{array}$ & $\begin{array}{l}0.0155 \\
(1.17)\end{array}$ & $\begin{array}{c}0.0333^{* * *} \\
(5.44)\end{array}$ & $\begin{array}{l}0.0321^{* * *} \\
\quad(4.06)\end{array}$ & $\begin{array}{c}0.0412^{* * *} \\
(3.73)\end{array}$ \\
\hline abnormal stock return (lagged) & $\begin{array}{c}-0.106^{* * *} \\
(-7.48)\end{array}$ & $\begin{array}{c}-0.0915^{* * *} \\
(-4.89)\end{array}$ & $\begin{array}{c}-0.111^{* * *} \\
(-6.12)\end{array}$ & $\begin{array}{c}-0.0962^{* * *} \\
(-7.81)\end{array}$ & $\begin{array}{c}-0.0508^{* * *} \\
(-3.73)\end{array}$ & $\begin{array}{c}-0.121^{* * *} \\
(-7.90)\end{array}$ \\
\hline stock return volatility (lagged) & $\begin{array}{c}0.311^{* * *} \\
(12.28)\end{array}$ & $\begin{array}{c}0.295^{* * *} \\
(8.85)\end{array}$ & $\begin{array}{c}0.319^{* * *} \\
(9.61)\end{array}$ & $\begin{array}{c}0.268^{* * *} \\
(13.08)\end{array}$ & $\begin{array}{c}0.176^{* * *} \\
(8.06)\end{array}$ & $\begin{array}{c}0.302^{* * *} \\
(12.28)\end{array}$ \\
\hline$\%$ foreign tax (lagged) & $\begin{array}{c}-0.0172^{* * *} \\
(-3.31)\end{array}$ & $\begin{array}{c}-0.0284^{* *} \\
(-2.18)\end{array}$ & $\begin{array}{c}-0.00947^{*} \\
(-1.85)\end{array}$ & $\begin{array}{c}-0.0105^{* * *} \\
(-2.93)\end{array}$ & $\begin{array}{c}-0.0132^{* *} \\
(-2.18)\end{array}$ & $\begin{array}{c}-0.00745^{*} \\
(-1.68)\end{array}$ \\
\hline high ind PO/COGS (lagged) & $\begin{array}{c}0.129^{* * *} \\
(2.72)\end{array}$ & $\begin{array}{c}0.369^{* * *} \\
(3.69)\end{array}$ & $\begin{array}{l}0.0255 \\
(0.57)\end{array}$ & $\begin{array}{c}0.0815^{* * *} \\
(2.96)\end{array}$ & $\begin{array}{c}0.172^{* * *} \\
(4.07)\end{array}$ & $\begin{array}{c}0.0402 \\
(1.24)\end{array}$ \\
\hline Observations & 7801 & 2543 & 5258 & 7801 & 2543 & 5258 \\
\hline Adjusted $R^{2}$ & 0.197 & 0.112 & 0.232 & 0.258 & 0.141 & 0.268 \\
\hline Fixed Effects & Ind, Year & Ind, Year & Ind, Year & Ind, Year & Ind, Year & Ind, Year \\
\hline
\end{tabular}


Table XI: Outsourcing, Leverage and Supplier Characteristics

The table examines the impact of outsourcing and supplier characteristics on financial leverage. We use an instrumental variable approach with close to port and high transp cost as instrumental variables for PO/COGS. high RED is an industry-level dummy variable that equals one if a given industry's $R \mathscr{E} D$ /sales is in the highest tercile. high supp RED is a firm-level dummy variable that equals one if the firm's average value of suppliers' R\&D intensity is in the highest tercile. high supp\# is a firm-level dummy variable that equals one if the firm's total number of suppliers is in the highest tercile. The sample is a subsample of customer firms whose suppliers are identified with the Capital IQ's business relationship database. All the control variables from the outsourcing intensity prediction regression (column six in Table VII) are included but not reported. t-statistics (in parenthesis) are robust and adjusted for industry-year clustering. ${ }^{* * *},{ }^{* *}$, and ${ }^{*}$ indicate statistical significance at $1 \%, 5 \%$, and $10 \%$ level, respectively.

\begin{tabular}{|c|c|c|c|c|c|c|}
\hline \multirow[t]{3}{*}{ Estimation Method } & \multicolumn{6}{|c|}{ Instrumental Variable Approach } \\
\hline & All & High R\&D & Low R\&D & All & High R\&D & Low $\mathrm{R} \& \mathrm{D}$ \\
\hline & \multicolumn{6}{|c|}{ market leverage } \\
\hline PO/COGS * high supp R\&D (instr.) & $\begin{array}{c}-1.005^{* *} \\
(-2.08)\end{array}$ & $\begin{array}{c}-2.132^{* * *} \\
(-3.11)\end{array}$ & $\begin{array}{c}-0.0452 \\
(-0.08)\end{array}$ & & & \\
\hline PO/COGS * high supp \# (instr.) & & & & $\begin{array}{c}-0.809^{* *} \\
(-2.56)\end{array}$ & $\begin{array}{c}-1.540^{* * *} \\
(-3.82)\end{array}$ & $\begin{array}{c}-0.0641 \\
(-0.17)\end{array}$ \\
\hline PO/COGS (instr.) & $\begin{array}{l}-0.245 \\
(-1.28)\end{array}$ & $\begin{array}{l}0.764 \\
(1.67)\end{array}$ & $\begin{array}{c}-0.456^{* *} \\
(-2.15)\end{array}$ & $\begin{array}{c}-0.00694 \\
(-0.03)\end{array}$ & $\begin{array}{c}1.091^{* *} \\
(2.53)\end{array}$ & $\begin{array}{c}-0.430^{*} \\
(-1.71)\end{array}$ \\
\hline high supp R\&D & $\begin{array}{c}0.109^{*} \\
(1.88)\end{array}$ & $\begin{array}{l}0.257^{* * *} \\
(3.20)\end{array}$ & $\begin{array}{c}-0.0165 \\
(-0.25)\end{array}$ & $\begin{array}{c}-0.00799^{*} \\
(-1.84)\end{array}$ & $\begin{array}{c}0.00811 \\
(1.46)\end{array}$ & $\begin{array}{c}-0.0217^{* * *} \\
\quad(-5.27)\end{array}$ \\
\hline high supp \# & $\begin{array}{c}-0.0129 * * * \\
(-3.24)\end{array}$ & $\begin{array}{l}0.000459 \\
(0.08)\end{array}$ & $\begin{array}{c}-0.0211^{* * *} \\
(-3.61)\end{array}$ & $\begin{array}{l}0.0763^{* *} \\
(2.14)\end{array}$ & $\begin{array}{c}0.170^{* * *} \\
(3.92)\end{array}$ & $\begin{array}{c}-0.0139 \\
(-0.33)\end{array}$ \\
\hline high $\%$ foreign supp & $\begin{array}{c}-0.00333 \\
(-0.70)\end{array}$ & $\begin{array}{c}0.0344^{* * *} \\
(10.03)\end{array}$ & $\begin{array}{c}-0.0222^{* * *} \\
(-4.74)\end{array}$ & $\begin{array}{c}-0.00803^{* *} \\
(-2.03)\end{array}$ & $\begin{array}{c}0.0245^{* * *} \\
(6.46)\end{array}$ & $\begin{array}{c}-0.0225^{* * *} \\
(-5.59)\end{array}$ \\
\hline$\%$ manufacturing supp & $\begin{array}{c}0.0130^{* *} \\
(2.08)\end{array}$ & $\begin{array}{l}0.0305^{* * *} \\
(3.72)\end{array}$ & $\begin{array}{c}0.00207 \\
(0.29)\end{array}$ & $\begin{array}{c}-0.000884 \\
(-0.25)\end{array}$ & $\begin{array}{c}0.00204 \\
(0.39)\end{array}$ & $\begin{array}{c}0.00125 \\
(0.25)\end{array}$ \\
\hline high supp labor & $\begin{array}{c}0.0115^{* * *} \\
\quad(3.36)\end{array}$ & $\begin{array}{c}0.0144^{* * *} \\
(3.59)\end{array}$ & $\begin{array}{c}0.00922^{*} \\
(1.85)\end{array}$ & $\begin{array}{c}-0.000266 \\
(-0.06)\end{array}$ & $\begin{array}{c}-0.00894^{*} \\
(-1.80)\end{array}$ & $\begin{array}{c}0.00845 \\
(1.57)\end{array}$ \\
\hline high supp HHI & $\begin{array}{c}-0.00660 \\
(-1.21)\end{array}$ & $\begin{array}{c}0.00850 \\
(0.57)\end{array}$ & $\begin{array}{c}-0.00335 \\
(-0.53)\end{array}$ & $\begin{array}{c}-0.0164^{* *} \\
(-2.54)\end{array}$ & $\begin{array}{c}-0.0131 \\
(-0.77)\end{array}$ & $\begin{array}{c}-0.00403 \\
(-0.60)\end{array}$ \\
\hline relative supp size small & $\begin{array}{c}0.00283 \\
(0.48)\end{array}$ & $\begin{array}{c}0.0136 \\
(0.99)\end{array}$ & $\begin{array}{c}0.00139 \\
(0.25)\end{array}$ & $\begin{array}{c}0.00534 \\
(0.99)\end{array}$ & $\begin{array}{c}0.0188 \\
(1.43)\end{array}$ & $\begin{array}{c}0.00147 \\
(0.29)\end{array}$ \\
\hline$\%$ foreign tax (lagged) & $\begin{array}{c}-0.00684^{* *} \\
(-2.01)\end{array}$ & $\begin{array}{c}-0.000218 \\
(-0.04)\end{array}$ & $\begin{array}{c}-0.00552 \\
(-1.13)\end{array}$ & $\begin{array}{c}-0.00665^{* *} \\
(-2.03)\end{array}$ & $\begin{array}{c}-0.000295 \\
(-0.05)\end{array}$ & $\begin{array}{c}-0.00558 \\
(-1.20)\end{array}$ \\
\hline high ind PO/COGS (lagged) & $\begin{array}{c}0.00676 \\
(1.17)\end{array}$ & $\begin{array}{c}-0.00351 \\
(-0.38)\end{array}$ & $\begin{array}{c}0.00477 \\
(0.57)\end{array}$ & $\begin{array}{c}0.00403 \\
(0.77)\end{array}$ & $\begin{array}{c}-0.00834 \\
(-0.95)\end{array}$ & $\begin{array}{c}0.00465 \\
(0.60)\end{array}$ \\
\hline Observations & 4669 & 1665 & 3004 & 4669 & 1665 & 3004 \\
\hline Adjusted R-squared & 0.284 & 0.158 & 0.321 & 0.284 & 0.158 & 0.321 \\
\hline Firm, Industry, Year Control Variables & Yes & Yes & Yes & Yes & Yes & Yes \\
\hline
\end{tabular}




\section{Table XII: Multinomial Logit Regression (Base: Public Debt Issue)}

The table presents coefficient estimates from a multinomial logistic regression testing the impact of outsourcing intensity on public and private security issues. The dependent variable is the relative log-odds of issuing each security type versus public debt. $P O / C O G S$ (instr) is the predicted outsourcing intensity using an instrumental variable approach with close to port and high transp cost as instrumental variables. All the control variables from the outsourcing intensity prediction regression (column six in Table VII are included and one-year lagged. Other variable definitions are available in the Appendix. Industry and year control variables are included but not reported. t-statistics (in parenthesis) are robust and adjusted for industry-year clustering. ${ }^{* * *},{ }^{* *}$, and * indicate statistical significance at $1 \%, 5 \%$, and $10 \%$ level, respectively.

\begin{tabular}{|c|c|c|c|c|c|}
\hline Base: Public Debt & Private Debt & Equity & Private Equity & Convertible & Private Convertible \\
\hline PO/COGS (instr.) & $\begin{array}{c}29.11^{* *} \\
(2.11)\end{array}$ & $\begin{array}{l}44.03^{*} \\
(1.80)\end{array}$ & $\begin{array}{l}14.90 \\
(0.51)\end{array}$ & $\begin{array}{l}14.83 \\
(0.76)\end{array}$ & $\begin{array}{l}8.722 \\
(0.33)\end{array}$ \\
\hline $\log ($ mv assets $)$ (lagged) & $\begin{array}{c}-1.285^{* * *} \\
(-5.19)\end{array}$ & $\begin{array}{c}-1.202^{* * *} \\
(-3.06)\end{array}$ & $\begin{array}{c}-1.757^{* * *} \\
(-3.69)\end{array}$ & $\begin{array}{c}-1.357^{* * *} \\
(-3.97)\end{array}$ & $\begin{array}{c}-1.749 * * * \\
(-3.95)\end{array}$ \\
\hline $\log (1+$ age $)$ & $\begin{array}{c}-0.939^{* * *} \\
(-4.45)\end{array}$ & $\begin{array}{c}-1.235 * * * \\
(-3.76)\end{array}$ & $\begin{array}{l}-0.754 \\
(-1.56)\end{array}$ & $\begin{array}{c}-1.632^{* * *} \\
(-5.39)\end{array}$ & $\begin{array}{c}-1.717^{* * *} \\
(-4.37)\end{array}$ \\
\hline PPE/assets (lagged) & $\begin{array}{l}0.822 \\
(1.29)\end{array}$ & $\begin{array}{l}0.336 \\
(0.33)\end{array}$ & $\begin{array}{l}-0.978 \\
(-0.74)\end{array}$ & $\begin{array}{l}-0.769 \\
(-1.00)\end{array}$ & $\begin{array}{c}0.0483 \\
(0.05)\end{array}$ \\
\hline operating margin (lagged) & $\begin{array}{c}-2.422^{*} \\
(-1.68)\end{array}$ & $\begin{array}{c}-3.430^{* *} \\
(-2.41)\end{array}$ & $\begin{array}{c}-3.160^{* *} \\
(-2.22)\end{array}$ & $\begin{array}{c}-3.310^{* *} \\
(-2.33)\end{array}$ & $\begin{array}{c}-3.323^{* *} \\
(-2.37)\end{array}$ \\
\hline cash flow volatility (lagged) & $\begin{array}{c}10.74^{* *} \\
(1.98)\end{array}$ & $\begin{array}{c}11.00 * * \\
(2.03)\end{array}$ & $\begin{array}{c}12.99^{* *} \\
(2.35)\end{array}$ & $\begin{array}{c}12.62^{* *} \\
(2.31)\end{array}$ & $\begin{array}{c}12.04^{* *} \\
(2.18)\end{array}$ \\
\hline M/B (lagged) & $\begin{array}{l}-0.182 \\
(-0.92)\end{array}$ & $\begin{array}{l}-0.131 \\
(-0.46)\end{array}$ & $\begin{array}{l}0.256 \\
(0.68)\end{array}$ & $\begin{array}{l}0.169 \\
(0.67)\end{array}$ & $\begin{array}{l}0.435 \\
(1.41)\end{array}$ \\
\hline abnormal stock return (lagged) & $\begin{array}{l}0.422 \\
(0.43)\end{array}$ & $\begin{array}{l}0.111 \\
(0.10)\end{array}$ & $\begin{array}{l}-1.479 \\
(-1.24)\end{array}$ & $\begin{array}{l}1.820^{*} \\
(1.74)\end{array}$ & $\begin{array}{l}-0.178 \\
(-0.13)\end{array}$ \\
\hline stock return volatility (lagged) & $\begin{array}{c}-4.670 * * * \\
(-3.59)\end{array}$ & $\begin{array}{l}-0.941 \\
(-0.50)\end{array}$ & $\begin{array}{l}-0.676 \\
(-0.26)\end{array}$ & $\begin{array}{l}2.353 \\
(1.50)\end{array}$ & $\begin{array}{l}1.867 \\
(0.88)\end{array}$ \\
\hline marginal tax rate (lagged) & $\begin{array}{l}2.466^{* * * *} \\
\quad(2.60)\end{array}$ & $\begin{array}{l}2.034^{*} \\
(1.70)\end{array}$ & $\begin{array}{l}1.308 \\
(0.52)\end{array}$ & $\begin{array}{l}0.779 \\
(0.47)\end{array}$ & $\begin{array}{l}-0.151 \\
(-0.07)\end{array}$ \\
\hline$\%$ foreign tax (lagged) & $\begin{array}{l}0.415 \\
(1.55)\end{array}$ & $\begin{array}{l}0.533 \\
(1.12)\end{array}$ & $\begin{array}{l}-0.481 \\
(-0.75)\end{array}$ & $\begin{array}{c}0.722^{* *} \\
(1.98)\end{array}$ & $\begin{array}{l}0.508 \\
(1.06)\end{array}$ \\
\hline default probability (lagged) & $\begin{array}{l}5.766 \\
(1.50)\end{array}$ & $\begin{array}{l}3.557 \\
(0.75)\end{array}$ & $\begin{array}{l}1.610 \\
(0.33)\end{array}$ & $\begin{array}{l}2.886 \\
(0.70)\end{array}$ & $\begin{array}{l}2.969 \\
(0.71)\end{array}$ \\
\hline $\begin{array}{l}\text { Observations } \\
\text { Pseudo R-squared } \\
\text { Ind, Year control }\end{array}$ & $\begin{array}{c}1408 \\
0.338 \\
\text { Yes }\end{array}$ & & & & \\
\hline
\end{tabular}


Table XIII: Nested Logit Regression (First Stage: Market Decision)

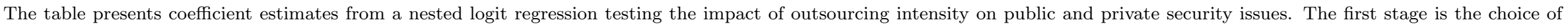

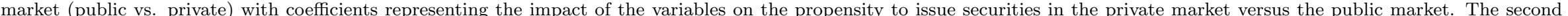

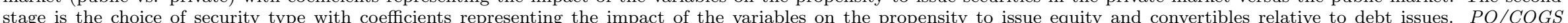

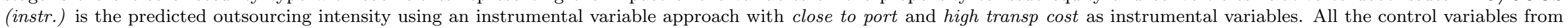

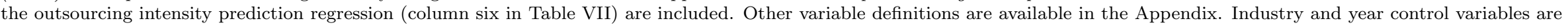

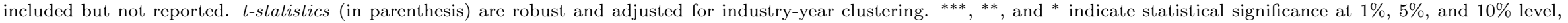
respectively.

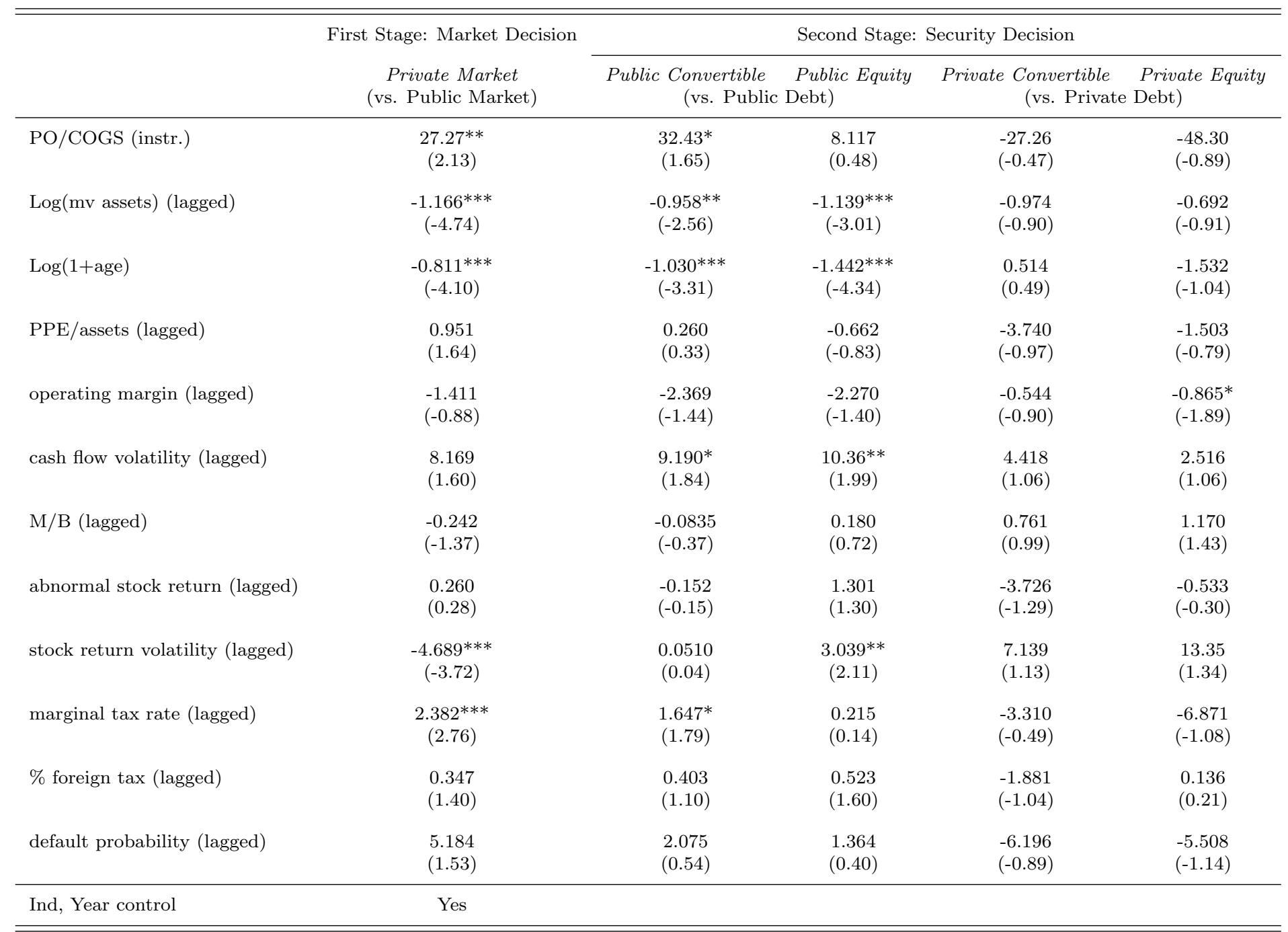


Table A.1: Outsourcing, Leverage with Accounts Payables and Measures of Human Capital

The table examines the impact of outsourcing and industry value added per employee on financial leverage. Leverage in the table is computed by additionally including account payables as part of total debt. We use an instrumental variable approach with close to port and high transp cost as instrumental variables for PO/COGS. high ind VAE is an industry-level dummy variable that equals one if a given industry's value added per employee (VAE) is greater than the sample median. high RED is an industry-level dummy variable that equals one if a given industry's $R \mathscr{E} D$ /sales is in the highest tercile. Other variable definitions are available in the Appendix. All the control variables from the outsourcing intensity prediction regression (column five in Table VII are included. t-statistics (in parenthesis) are robust and adjusted for industry-year clustering. ${ }^{* * *},{ }^{* *}$, and ${ }^{*}$ indicate statistical significance at $1 \%, 5 \%$, and $10 \%$ level, respectively.

\begin{tabular}{|c|c|c|c|c|c|c|}
\hline \multirow[t]{3}{*}{ Estimation Method } & \multicolumn{6}{|c|}{ Instrumental Variable Approach } \\
\hline & All & High R\&D & Low R\&D & All & High R\&D & Low $R \& D$ \\
\hline & \multicolumn{3}{|c|}{ book leverage (with AP) } & \multicolumn{3}{|c|}{ market leverage (with AP) } \\
\hline PO/COGS * high ind VAE (instr.) & $\begin{array}{c}-2.562^{* * *} \\
(-2.80)\end{array}$ & $\begin{array}{c}-5.879^{* * *} \\
(-3.71)\end{array}$ & $\begin{array}{l}-1.267 \\
(-1.23)\end{array}$ & $\begin{array}{c}-4.405^{* * *} \\
(-2.94)\end{array}$ & $\begin{array}{c}-12.10^{* * *} \\
(-3.70)\end{array}$ & $\begin{array}{l}-1.144 \\
(-0.82)\end{array}$ \\
\hline PO/COGS (instr.) & $\begin{array}{l}0.0117 \\
(0.03)\end{array}$ & $\begin{array}{c}1.767^{* *} \\
(2.42)\end{array}$ & $\begin{array}{l}-0.362 \\
(-0.96)\end{array}$ & $\begin{array}{l}0.360 \\
(0.63)\end{array}$ & $\begin{array}{c}3.919^{* * *} \\
(2.93)\end{array}$ & $\begin{array}{l}-0.793 \\
(-1.61)\end{array}$ \\
\hline high ind VAE & $\begin{array}{c}0.00525 \\
(0.95)\end{array}$ & $\begin{array}{c}0.00305 \\
(0.52)\end{array}$ & $\begin{array}{c}0.00793 \\
(1.12)\end{array}$ & $\begin{array}{c}0.0122^{*} \\
(1.96)\end{array}$ & $\begin{array}{c}0.00532 \\
(0.56)\end{array}$ & $\begin{array}{c}0.0127^{* *} \\
(2.05)\end{array}$ \\
\hline $\log ($ mv assets) (lagged) & $\begin{array}{c}0.0352^{* * *} \\
(11.63)\end{array}$ & $\begin{array}{c}0.0281^{* * *} \\
(4.86)\end{array}$ & $\begin{array}{c}0.0342^{* * *} \\
(9.66)\end{array}$ & $\begin{array}{c}0.0578^{* * *} \\
(14.61)\end{array}$ & $\begin{array}{c}0.0517^{* * *} \\
(5.04)\end{array}$ & $\begin{array}{c}0.0561^{* * *} \\
(12.42)\end{array}$ \\
\hline $\log (1+$ age $)$ & $\begin{array}{c}-0.0114^{* *} \\
(-2.47)\end{array}$ & $\begin{array}{c}-0.00201 \\
(-0.47)\end{array}$ & $\begin{array}{c}-0.0167^{* * *} \\
(-2.94)\end{array}$ & $\begin{array}{c}-0.0109^{* *} \\
(-2.06)\end{array}$ & $\begin{array}{c}0.00379 \\
(0.73)\end{array}$ & $\begin{array}{c}-0.0187^{* * *} \\
(-2.98)\end{array}$ \\
\hline PPE/assets (lagged) & $\begin{array}{c}0.0201^{*} \\
(1.84)\end{array}$ & $\begin{array}{c}0.0412 \\
(1.73)\end{array}$ & $\begin{array}{l}0.0188 \\
(1.46)\end{array}$ & $\begin{array}{l}0.0155 \\
(1.07)\end{array}$ & $\begin{array}{c}0.0331 \\
(0.87)\end{array}$ & $\begin{array}{c}0.0138 \\
(0.83)\end{array}$ \\
\hline operating margin (lagged) & $\begin{array}{c}-0.00352^{* * *} \\
(-2.89)\end{array}$ & $\begin{array}{c}-0.00775^{* * *} \\
(-3.60)\end{array}$ & $\begin{array}{c}-0.00246 \\
(-0.58)\end{array}$ & $\begin{array}{c}-0.00903^{* * *} \\
(-4.09)\end{array}$ & $\begin{array}{c}-0.0166^{* * *} \\
(-3.61)\end{array}$ & $\begin{array}{c}-0.0136^{* *} \\
(-2.43)\end{array}$ \\
\hline cash flow volatility (lagged) & $\begin{array}{c}-0.0185^{* *} \\
(-2.14)\end{array}$ & $\begin{array}{c}-0.0189^{* *} \\
(-2.12)\end{array}$ & $\begin{array}{c}-0.00844 \\
(-0.26)\end{array}$ & $\begin{array}{l}0.0138 \\
(0.78)\end{array}$ & $\begin{array}{c}0.00499 \\
(0.24)\end{array}$ & $\begin{array}{l}0.0334 \\
(0.97)\end{array}$ \\
\hline M/B (lagged) & $\begin{array}{c}-0.0425^{* * *} \\
(-11.08)\end{array}$ & $\begin{array}{c}-0.0390^{* * *} \\
\quad(-6.74)\end{array}$ & $\begin{array}{c}-0.0594^{* * *} \\
(-12.58)\end{array}$ & $\begin{array}{c}-0.0243^{* * *} \\
(-4.86)\end{array}$ & $\begin{array}{c}-0.0449^{* * *} \\
(-4.03)\end{array}$ & $\begin{array}{c}-0.0228^{* * *} \\
(-3.55)\end{array}$ \\
\hline sales growth (lagged) & $\begin{array}{l}0.0379^{* * *} \\
\quad(5.97)\end{array}$ & $\begin{array}{c}0.0350^{* * *} \\
\quad(4.53)\end{array}$ & $\begin{array}{l}0.0491^{* * *} \\
(4.22)\end{array}$ & $\begin{array}{c}0.0367^{* * *} \\
(3.61)\end{array}$ & $\begin{array}{c}0.0531^{* *} \\
(2.89)\end{array}$ & $\begin{array}{l}0.0224 \\
(1.65)\end{array}$ \\
\hline abnormal stock return (lagged) & $\begin{array}{c}-0.120^{* * *} \\
(-8.63)\end{array}$ & $\begin{array}{c}-0.0757^{* * *} \\
\quad(-4.82)\end{array}$ & $\begin{array}{c}-0.146^{* * *} \\
(-8.23)\end{array}$ & $\begin{array}{c}-0.120^{* * *} \\
(-7.63)\end{array}$ & $\begin{array}{c}-0.128^{* * *} \\
(-6.50)\end{array}$ & $\begin{array}{c}-0.114^{* * *} \\
(-5.46)\end{array}$ \\
\hline stock return volatility (lagged) & $\begin{array}{c}0.351^{* * *} \\
(14.53)\end{array}$ & $\begin{array}{c}0.246^{* * *} \\
(6.61)\end{array}$ & $\begin{array}{c}0.394^{* * *} \\
(14.78)\end{array}$ & $\begin{array}{c}0.422^{* * *} \\
(15.68)\end{array}$ & $\begin{array}{c}0.424^{* * *} \\
(11.60)\end{array}$ & $\begin{array}{c}0.429^{* * *} \\
(12.30)\end{array}$ \\
\hline$\%$ foreign tax (lagged) & $\begin{array}{c}-0.00750^{* *} \\
(-2.05)\end{array}$ & $\begin{array}{c}-0.0127^{* *} \\
(-2.36)\end{array}$ & $\begin{array}{c}-0.00351 \\
(-0.77)\end{array}$ & $\begin{array}{c}-0.0140^{* * *} \\
(-2.77)\end{array}$ & $\begin{array}{c}-0.0282^{* *} \\
(-2.50)\end{array}$ & $\begin{array}{c}-0.00505 \\
(-0.97)\end{array}$ \\
\hline high ind PO/COGS (lagged) & $\begin{array}{c}0.0929^{* * *} \\
\quad(3.16)\end{array}$ & $\begin{array}{c}0.176^{* * *} \\
(3.85)\end{array}$ & $\begin{array}{c}0.0556 \\
(1.62)\end{array}$ & $\begin{array}{c}0.149^{* * *} \\
(3.20)\end{array}$ & $\begin{array}{c}0.369^{* * *} \\
(3.62)\end{array}$ & $\begin{array}{c}0.0546 \\
(1.20)\end{array}$ \\
\hline Observations & 7801 & 2543 & 5258 & 7801 & 2543 & 5258 \\
\hline Adjusted $R^{2}$ & 0.304 & 0.160 & 0.302 & 0.196 & 0.089 & 0.217 \\
\hline Fixed Effects & Ind, Year & Ind, Year & Ind, Year & Ind, Year & Ind, Year & Ind, Year \\
\hline
\end{tabular}


Table A.2: Outsourcing, Leverage with Accounts Payables and Supplier Characteristics

The table examines the impact of outsourcing and supplier characteristics on financial leverage. Leverage in the table is computed by additionally including account payables as part of total debt. We use an instrumental variable approach with close to port and high transp cost as instrumental variables for PO/COGS. high RED is an industry-level dummy variable that equals one if a given industry's $R \mathcal{E} D$ /sales is in the highest tercile. high supp $R \mathscr{G} D$ is a firm-level dummy variable that equals one if the firm's average value of suppliers' R\&D intensity is in the highest tercile. high supp\# is a firm-level dummy variable that equals one if the firm's total number of suppliers is in the highest tercile. The sample is a subsample of customer firms whose suppliers are identified with the Capital IQ's business relationship database. All the control variables from the outsourcing intensity prediction regression (column six in Table VII are included but not reported. t-statistics (in parenthesis) are robust and adjusted for industry-year clustering. ${ }^{* * *},{ }^{* *}$, and ${ }^{*}$ indicate statistical significance at $1 \%, 5 \%$, and $10 \%$ level, respectively.

\begin{tabular}{|c|c|c|c|c|c|c|}
\hline \multirow[t]{3}{*}{ Estimation Method } & \multicolumn{6}{|c|}{ Instrumental Variable Approach } \\
\hline & All & High R\&D & Low $\mathrm{R} \& \mathrm{D}$ & All & High R\&D & Low R\&D \\
\hline & \multicolumn{6}{|c|}{ market leverage (with $A P$ ) } \\
\hline PO/COGS * high supp R\&D (instr.) & $\begin{array}{c}-1.758^{* * *} \\
(-3.69)\end{array}$ & $\begin{array}{c}-2.799^{* * *} \\
(-4.08)\end{array}$ & $\begin{array}{l}-0.665 \\
(-1.18)\end{array}$ & & & \\
\hline PO/COGS * high supp \# (instr.) & & & & $\begin{array}{c}-0.809^{* *} \\
(-2.56)\end{array}$ & $\begin{array}{c}-1.540^{* * *} \\
(-3.82)\end{array}$ & $\begin{array}{c}-0.0641 \\
(-0.17)\end{array}$ \\
\hline PO/COGS (instr.) & $\begin{array}{l}0.104 \\
(0.43)\end{array}$ & $\begin{array}{c}1.294^{* *} \\
(2.10)\end{array}$ & $\begin{array}{l}-0.140 \\
(-0.58)\end{array}$ & $\begin{array}{c}-0.00694 \\
(-0.03)\end{array}$ & $\begin{array}{c}1.091^{* *} \\
(2.53)\end{array}$ & $\begin{array}{c}-0.430^{*} \\
(-1.71)\end{array}$ \\
\hline high supp R\&D & $\begin{array}{c}0.191^{* * *} \\
(3.31)\end{array}$ & $\begin{array}{c}0.329^{* * *} \\
(4.08)\end{array}$ & $\begin{array}{c}0.0503 \\
(0.74)\end{array}$ & $\begin{array}{c}-0.00799^{*} \\
(-1.84)\end{array}$ & $\begin{array}{c}0.00811 \\
(1.46)\end{array}$ & $\begin{array}{c}-0.0217^{* * *} \\
(-5.27)\end{array}$ \\
\hline high supp \# & $\begin{array}{c}0.000384 \\
(0.09)\end{array}$ & $\begin{array}{c}0.00980 \\
(1.23)\end{array}$ & $\begin{array}{c}-0.00587 \\
(-0.99)\end{array}$ & $\begin{array}{c}0.0763^{* *} \\
(2.14)\end{array}$ & $\begin{array}{c}0.170^{* * *} \\
(3.92)\end{array}$ & $\begin{array}{c}-0.0139 \\
(-0.33)\end{array}$ \\
\hline high $\%$ foreign supp & $\begin{array}{c}-0.00244 \\
(-0.47)\end{array}$ & $\begin{array}{c}0.0379^{* * *} \\
(8.56)\end{array}$ & $\begin{array}{c}-0.0222^{* * *} \\
(-4.37)\end{array}$ & $\begin{array}{c}-0.00803^{* *} \\
(-2.03)\end{array}$ & $\begin{array}{c}0.0245^{* * *} \\
(6.46)\end{array}$ & $\begin{array}{c}-0.0225^{* * *} \\
(-5.59)\end{array}$ \\
\hline$\%$ manufacturing supp & $\begin{array}{c}0.0264^{* * *} \\
\quad(4.28)\end{array}$ & $\begin{array}{c}0.0280^{* * *} \\
(3.18)\end{array}$ & $\begin{array}{c}0.0225^{* * *} \\
(2.90)\end{array}$ & $\begin{array}{c}-0.000884 \\
(-0.25)\end{array}$ & $\begin{array}{c}0.00204 \\
(0.39)\end{array}$ & $\begin{array}{c}0.00125 \\
(0.25)\end{array}$ \\
\hline high supp labor & $\begin{array}{c}0.0178^{* * *} \\
\quad(5.00)\end{array}$ & $\begin{array}{c}0.0287^{* * *} \\
(8.89)\end{array}$ & $\begin{array}{c}0.0116^{* *} \\
(2.32)\end{array}$ & $\begin{array}{c}-0.000266 \\
(-0.06)\end{array}$ & $\begin{array}{c}-0.00894^{*} \\
(-1.80)\end{array}$ & $\begin{array}{c}0.00845 \\
(1.57)\end{array}$ \\
\hline high supp HHI & $\begin{array}{c}-0.00119 \\
(-0.18)\end{array}$ & $\begin{array}{c}0.0162 \\
(0.87)\end{array}$ & $\begin{array}{c}0.00173 \\
(0.24)\end{array}$ & $\begin{array}{c}-0.0164^{* *} \\
(-2.54)\end{array}$ & $\begin{array}{c}-0.0131 \\
(-0.77)\end{array}$ & $\begin{array}{c}-0.00403 \\
(-0.60)\end{array}$ \\
\hline relative supp size small & $\begin{array}{c}0.00609 \\
(0.90)\end{array}$ & $\begin{array}{c}0.0279 \\
(1.67)\end{array}$ & $\begin{array}{c}0.00106 \\
(0.17)\end{array}$ & $\begin{array}{c}0.00534 \\
(0.99)\end{array}$ & $\begin{array}{c}0.0188 \\
(1.43)\end{array}$ & $\begin{array}{c}0.00147 \\
(0.29)\end{array}$ \\
\hline$\%$ foreign tax (lagged) & $\begin{array}{c}-0.00547 \\
(-1.45)\end{array}$ & $\begin{array}{c}0.00135 \\
(0.21)\end{array}$ & $\begin{array}{c}-0.00255 \\
(-0.50)\end{array}$ & $\begin{array}{c}-0.00665^{* *} \\
(-2.03)\end{array}$ & $\begin{array}{c}-0.000295 \\
(-0.05)\end{array}$ & $\begin{array}{c}-0.00558 \\
(-1.20)\end{array}$ \\
\hline high ind PO/COGS (lagged) & $\begin{array}{c}0.00658 \\
(0.99)\end{array}$ & $\begin{array}{c}-0.00514 \\
(-0.45)\end{array}$ & $\begin{array}{c}0.00325 \\
(0.34)\end{array}$ & $\begin{array}{c}0.00403 \\
(0.77)\end{array}$ & $\begin{array}{c}-0.00834 \\
(-0.95)\end{array}$ & $\begin{array}{c}0.00465 \\
(0.60)\end{array}$ \\
\hline Observations & 4669 & 1665 & 3004 & 4669 & 1665 & 3004 \\
\hline Adjusted $R^{2}$ & 0.336 & 0.207 & 0.362 & 0.284 & 0.158 & 0.321 \\
\hline
\end{tabular}


Table A.3: Supplier Characteristics

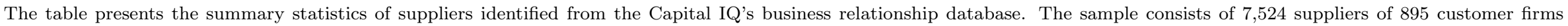

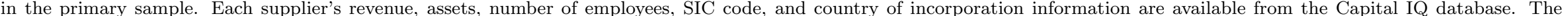

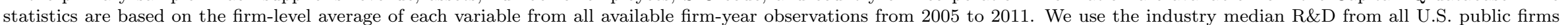
with the same 4-digit SIC code to proxy foreign or U.S. private suppliers' R\&D.

\begin{tabular}{|c|c|c|c|c|c|c|c|}
\hline & \multicolumn{7}{|c|}{ Supplier Characteristics } \\
\hline & mean & $\min$ & p25 & p50 & $\mathrm{p} 75$ & $\max$ & $\mathrm{N}$ \\
\hline Supplier Revenue (\$million) & 4588.380 & 0 & 50.007 & 244.643 & 1723.143 & 2384814.250 & 5294 \\
\hline Supplier Assets (\$million) & 7781.699 & 0 & 63.025 & 304.629 & 2344.114 & 2421008.500 & 5295 \\
\hline Supplier Capital Intensity (sales/assets) & 0.944 & 0.035 & 0.577 & 0.845 & 1.188 & 3.022 & 5290 \\
\hline Supplier Labor Intensity (employees/revenue) & 8.144 & 0.069 & 2.992 & 4.972 & 8.754 & 65.480 & 4915 \\
\hline Supplier R\&D Intensity (R\&D/sales) & 0.102 & 0 & 0.004 & 0.087 & 0.125 & 0.763 & 5119 \\
\hline Supplier in Manufacturing & 0.474 & 0 & 0 & 0 & 1 & 1 & 6937 \\
\hline U.S. Public Supplier & 0.320 & 0 & 0 & 0 & 1 & 1 & 6937 \\
\hline Region: Asia/Pacific & 0.209 & 0 & 0 & 0 & 0 & 1 & 6937 \\
\hline Region: Africa/Middle East & 0.018 & 0 & 0 & 0 & 0 & 1 & 6937 \\
\hline Region: Europe & 0.155 & 0 & 0 & 0 & 0 & 1 & 6937 \\
\hline Region: Latin America/Caribbean & 0.011 & 0 & 0 & 0 & 0 & 1 & 6937 \\
\hline Region: US/Canada & 0.462 & 0 & 0 & 0 & 1 & 1 & 6937 \\
\hline Region: Other than US/Canada & 0.519 & 0 & 0 & 1 & 1 & 1 & 6937 \\
\hline Region: Other than US/Canada/Europe & 0.383 & 0 & 0 & 0 & 1 & 1 & 6937 \\
\hline Region: Unknown & 0.145 & 0 & 0 & 0 & 0 & 1 & 6937 \\
\hline
\end{tabular}

